\title{
Lithologic Descriptions, Geophysical Logs, and Source-Rock Geochemistry of the U.S. Geological Survey Alcova Reservoir AR-1-13 Core Hole, Natrona County, Wyoming
}

Scientific Investigations Report 2019-5123

Version 1.1, November 2021 


\section{Lithologic Descriptions, Geophysical Logs, and Source-Rock Geochemistry of the U.S. Geological Survey Alcova Reservoir AR-1-13 Core Hole, Natrona County, Wyoming}

By Mark A. Kirschbaum, Thomas M. Finn, Christopher J. Schenk, and Sarah J. Hawkins

Scientific Investigations Report 2019-5123

Version 1.1, November 2021 


\section{U.S. Geological Survey, Reston, Virginia: 2019 First release: 2019 \\ Revised: November 2021 (ver. 1.1)}

For more information on the USGS — the Federal source for science about the Earth, its natural and living resources, natural hazards, and the environment-visit https://www.usgs.gov or call 1-888-ASK-USGS.

For an overview of USGS information products, including maps, imagery, and publications, visit https://store.usgs.gov.

Any use of trade, firm, or product names is for descriptive purposes only and does not imply endorsement by the U.S. Government.

Although this information product, for the most part, is in the public domain, it also may contain copyrighted materials as noted in the text. Permission to reproduce copyrighted items must be secured from the copyright owner.

Suggested citation:

Kirschbaum, M.A., Finn, T.M., Schenk, C.J., and Hawkins, S.J., 2019, Lithologic descriptions, geophysical logs, and source-rock geochemistry of the U.S. Geological Survey Alcova Reservoir AR-1-13 core hole, Natrona County, Wyoming (ver. 1.1, November 2021): U.S. Geological Survey Scientific Investigations Report 2019-5123, 33 p., https://doi.org/10.3133/sir20195123.

Associated data for this report:

Finn, T.M., Kirschbaum, M.A., and Schenk, C.J., 2019, Total organic carbon and pyrolysis analysis data for the U.S. Geological Survey Alcova AR-1-13 core hole, Natrona County, Wyoming (ver. 1.1, November 2021): U.S. Geological Survey data release, https://doi.org/10.5066/PgVLAKVG.

ISSN 2328-0328 (online) 


\section{Contents}

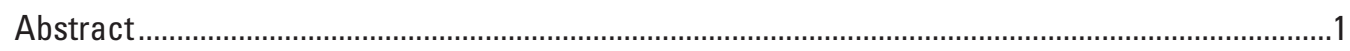

Introduction

Geophysical Logs

Stratigraphy

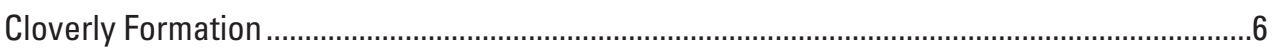

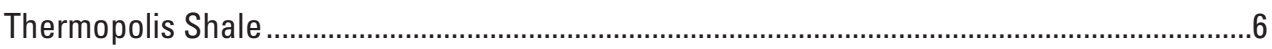

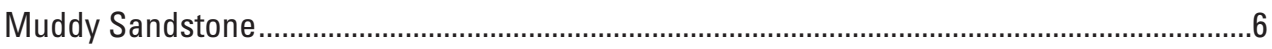

Mowry Shale

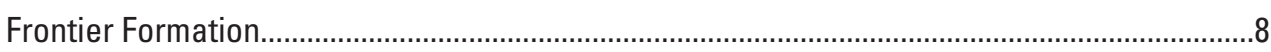

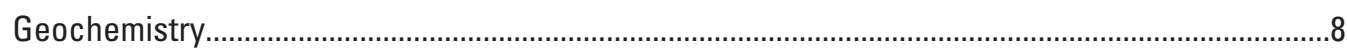

Quantity of Organic Matter ...............................................................................................

Types of Organic Matter ..................................................................................................

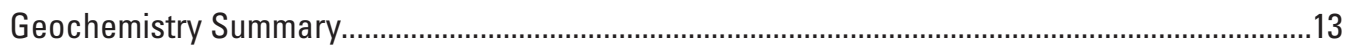

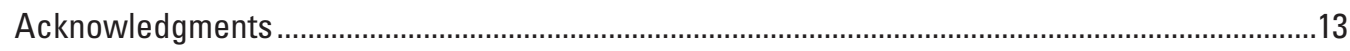

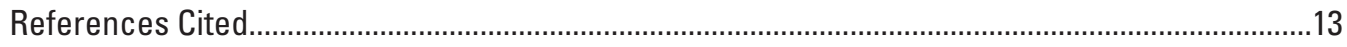

Appendix 1. Detailed Core Descriptions of the USGS AR-1-13 Core Hole, Natrona County,

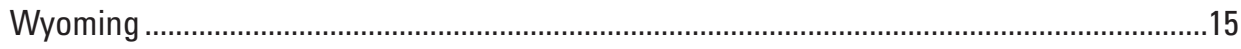

Appendix 2. Geophysical Logs of the USGS AR-1-13 Core Hole, Natrona County, Wyoming ....31

\section{Figures}

1. Map of southeastern part of the Wind River Basin showing location of the U.S. Geological Survey Alcova Reservoir AR-1-13 core hole...

2. Index map of the southeastern part of the Wind River Basin showing major structural elements (Finn, 2019), location of U.S. Geological Survey Alcova Reservoir AR-1-13 core hole, and location of the southeast-northwest subsurface cross section shown on figure 5 .................................................................................

3. Stratigraphic chart of Lower and lowermost Upper Cretaceous rocks in the southeastern part of the Wind River Basin ...............................................................

4. Graphic log of U.S. Geological Survey Alcova Reservoir AR-1-13 core hole showing lithology, and comparison to gamma ray and conductivity logs ...

5. Subsurface stratigraphic cross section showing correlation of Lower Cretaceous and lowermost Upper Cretaceous strata in the U.S. Geological Survey Alcova Reservoir AR-1-13 core hole with nearby wells in the southeastern part of the Wind River Basin

6. Gamma ray and conductivity logs of U.S. Geological Survey Alcova Reservoir AR-1-13 core hole showing relation of stratigraphic intervals to organic richness and kerogen type

7. Cross plot of $\mathrm{S}_{2}$ and total organic carbon for samples from the U.S. Geological Survey Alcova Reservoir AR-1-13 core hole

8. Cross plot of hydrogen index and oxygen index for samples from the U.S. Geological Survey Alcova Reservoir AR-1-13 core hole

\section{Tables}

1. Total organic carbon and pyrolysis data for the U.S. Geological Survey Alcova Reservoir AR-1-13 core hole 



\title{
Lithologic Descriptions, Geophysical Logs, and Source- Rock Geochemistry of the U.S. Geological Survey Alcova Reservoir AR-1-13 Core Hole, Natrona County, Wyoming
}

\author{
By Mark A. Kirschbaum, Thomas M. Finn, Christopher J. Schenk, and Sarah J. Hawkins
}

\begin{abstract}
In 2013, a continuous 624-ft core hole was drilled and logged by the U.S. Geological Survey in Natrona County, Wyoming, with the goal to better understand Cretaceous source rocks in the Wind River Basin. The core hole, named the Alcova Reservoir AR-1-13, penetrated the interval extending from the upper part of the Lower Cretaceous Cloverly Formation to the lower part of the Upper Cretaceous Frontier Formation. The lithologies are predominantly mudrock, with minor amounts of sandstone and altered volcanic ash beds that were deposited in open marine, nearshore marine, and fluvial settings.

Samples were collected from open marine clay-rich, dark-colored mudrocks, and these were analyzed for total organic carbon content and by programmed pyrolysis analysis. The results show that the lower part of the Frontier Formation, Shell Creek Shale equivalent, and the Thermopolis Shale contain Type III gas-prone kerogen, with poor to fair generative source rock potential. The upper part of the Mowry Shale has good to excellent generative potential, with organic matter composed mainly of Type II oil-prone kerogen with some mixed Type II/III kerogen capable of generating oil and gas.
\end{abstract}

\section{Introduction}

In 2005, the U.S. Geological Survey (USGS) quantitatively assessed the technically recoverable oil and gas resources of the Wind River Basin in Wyoming (Kirschbaum and others, 2005; Johnson and others, 2007). The assessment results show high hydrocarbon potential in sandstone reservoirs sourced from Lower and Upper Cretaceous organicrich mudrocks (Johnson and others, 2007). Sandstones in the Frontier-Muddy Continuous Gas Assessment Unit have high hydrocarbon potential and are thought to be sourced from intervening marine shales, particularly the Mowry and Thermopolis Shales (for example, see Burtner and Warner, 1984). There are other potential source rock intervals within the assessment unit; however, there are limited geologic and geochemical data available for these units (Finn, 2007a). Therefore, additional study of other potential source rock intervals would aid future assessments of the oil and gas potential of the Wind River Basin. Determining where to conduct such a study requires (1) a location along the shallow margin of the basin in order to obtain samples that have not been subjected to the effects of deep burial and therefore are immature with respect to hydrocarbon generation; (2) a location where little clastic input during deposition would dilute the organic matter; and (3) a relatively undeformed sedimentary section. A location fulfilling these criteria was identified in the southeastern part of the basin near Alcova Reservoir (fig. 1).

A continuous core hole, the Alcova Reservoir AR-1-13, was drilled and logged by the USGS in August 2013 on public land in Natrona County, Wyoming, about 30 miles southwest of Casper, Wyoming, in support of the National and Global Assessment of Oil and Gas Resources Project. The core hole is located on the northeast flank of the Alcova anticline in T. 30 N., R. 82 W., sec. 7, at lat 42.575145 degrees and long 106.70383 degrees (figs. 1 and 2). Core was recovered between 40.5 and 623 feet (ft) below surface, an interval of $582.5 \mathrm{ft}$, of which, 94 percent of the rock was recovered. Coring began in the lower part of the Frontier Formation and ended in the upper part of the Cloverly Formation (fig. 3).

The core hole was drilled by personnel of the USGS during multiple days and was completed on August 8, 2013. Surface casing was set to $40.5 \mathrm{ft}$ and coring began immediately below. Cores were collected in $15 \mathrm{ft}$ sections and boxed on location by the site geologist and a representative of the USGS Core Research Center (CRC). The core hole was subsequently logged by the USGS using standard geophysical techniques including natural gamma, resistivity, conductivity, density, sonic, and caliper with digital data collected to a depth of $624 \mathrm{ft}$.

Cores were transported to the CRC located at the Denver Federal Center in Lakewood, Colorado, where they were slabbed and reboxed, approximately $12 \mathrm{ft}$ to a box, totaling 45 boxes. Butt ends were returned to the field boxes and then sampled for geochemical analysis. Both the slabbed and butts are archived at the CRC with the library number F215.

The core was described at several levels of detail, sampled for geochemical analysis, and photographed. The core is portrayed as graphic logs at $1 \mathrm{inch}$ (in.) $=5 \mathrm{ft}$ (appendix 1) and at 1.5 in. $=100 \mathrm{ft} \mathrm{(fig.} \mathrm{4).}$ 


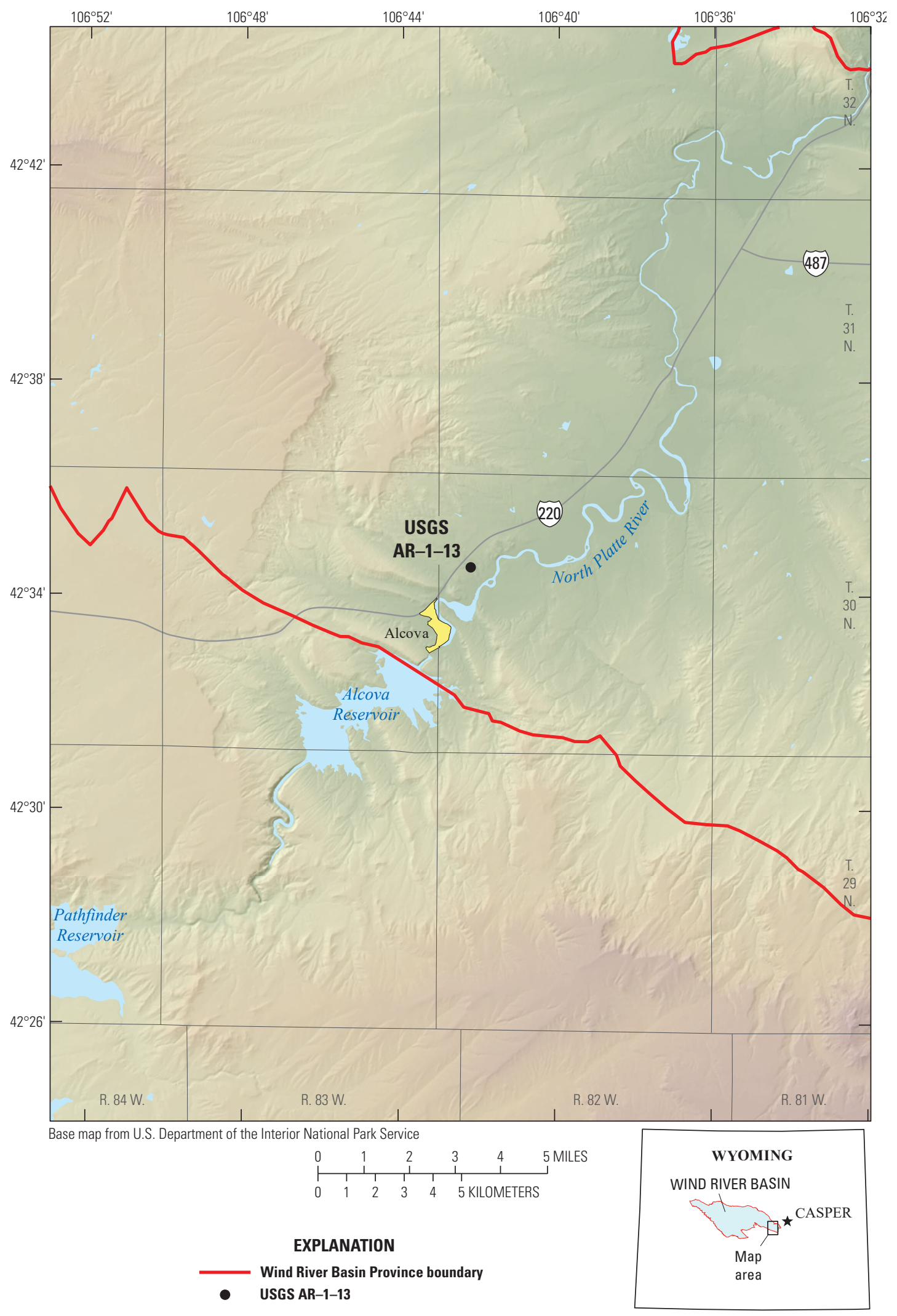

Figure 1. Southeastern part of the Wind River Basin showing location of the U.S. Geological Survey Alcova Reservoir AR-1-13 core hole. 


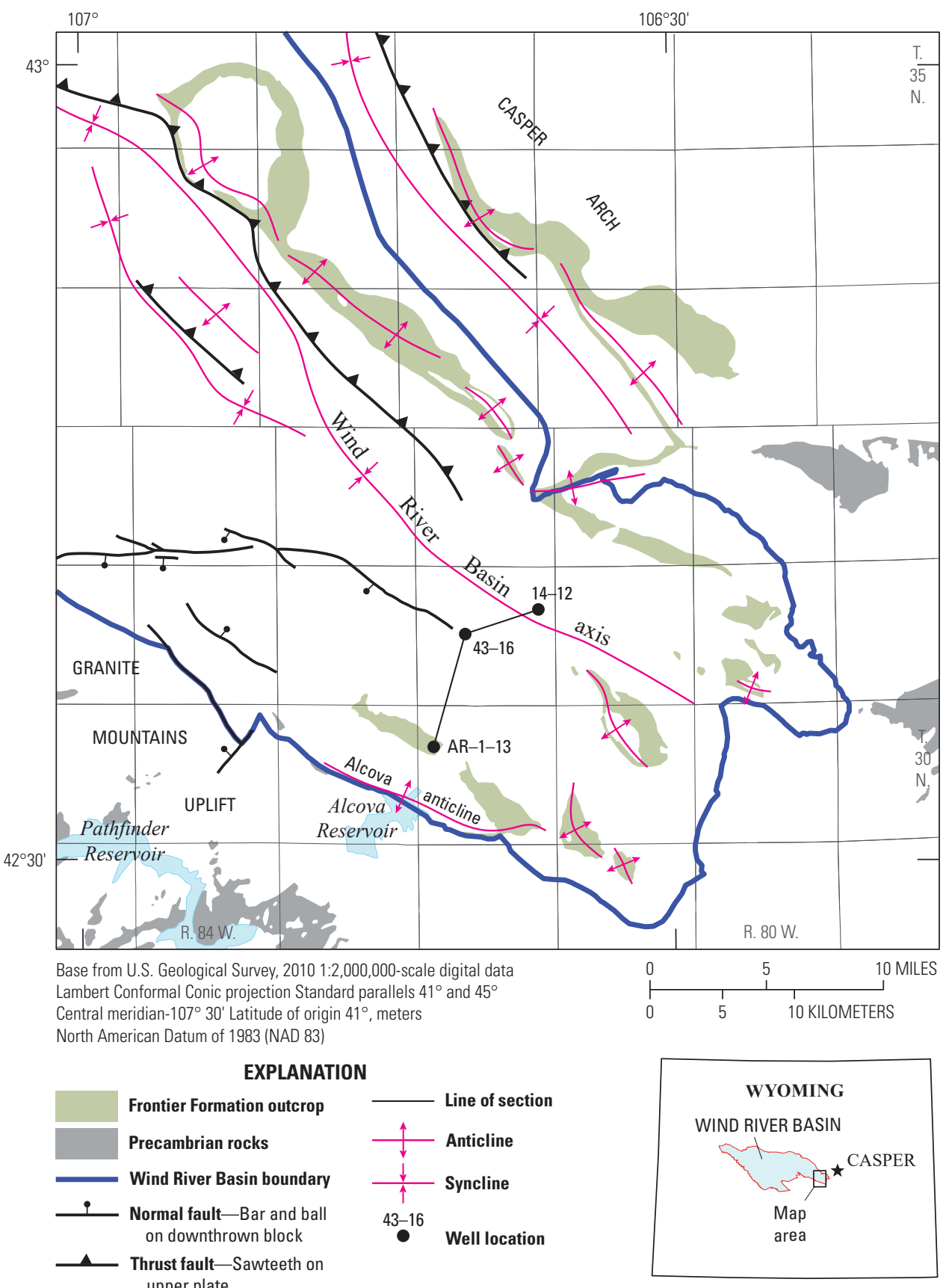

Figure 2. Southeastern part of the Wind River Basin showing major structural elements (Finn, 2019), location of U.S. Geological Survey Alcova Reservoir AR-1-13 core hole, and location of the southeast-northwest subsurface cross section shown on figure 5 . 


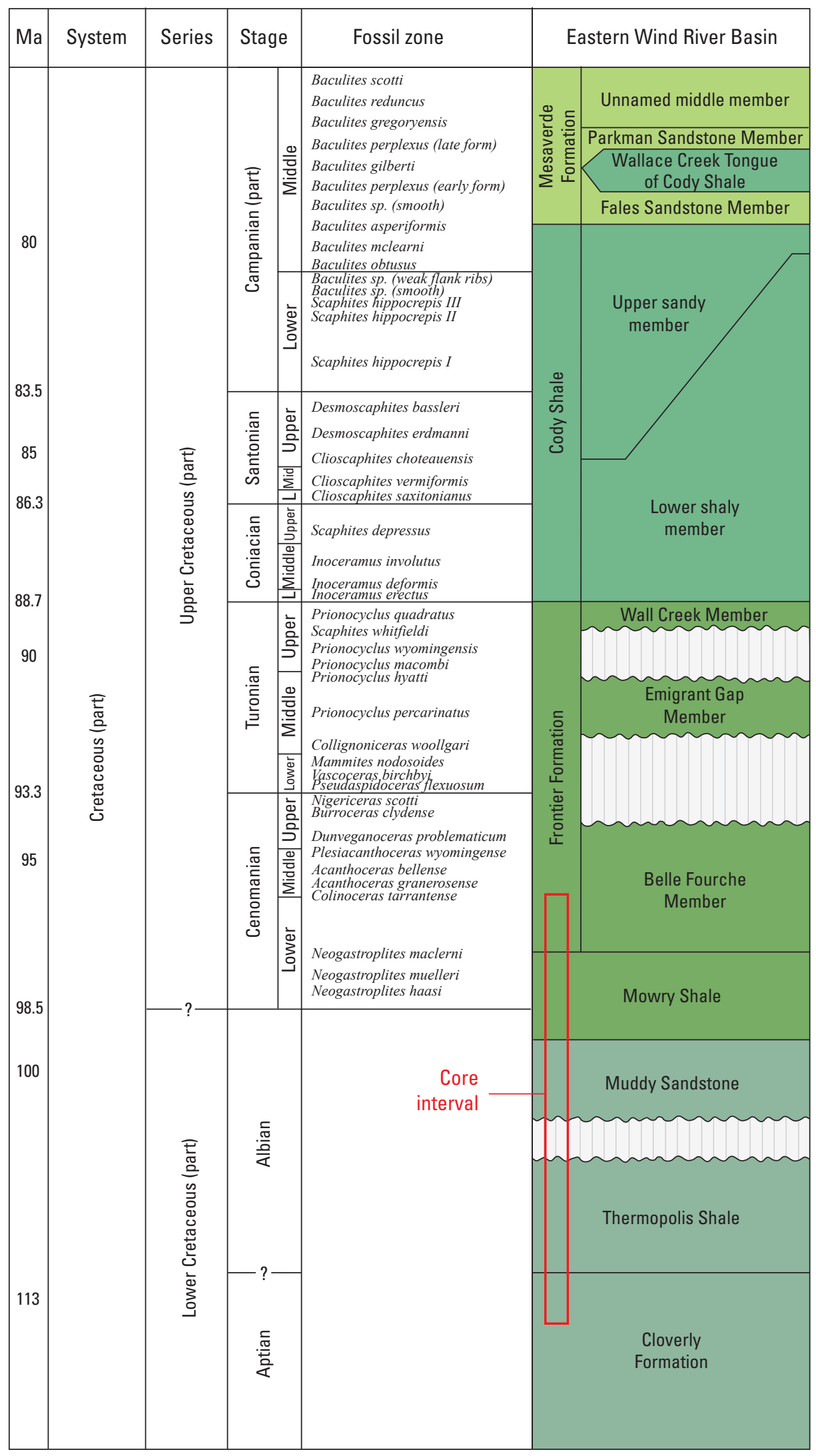

Figure 3. Lower and lowermost Upper Cretaceous rocks in the southeastern part of the Wind River Basin. Modified from Finn, 2007b. [Ma, million years before present] 


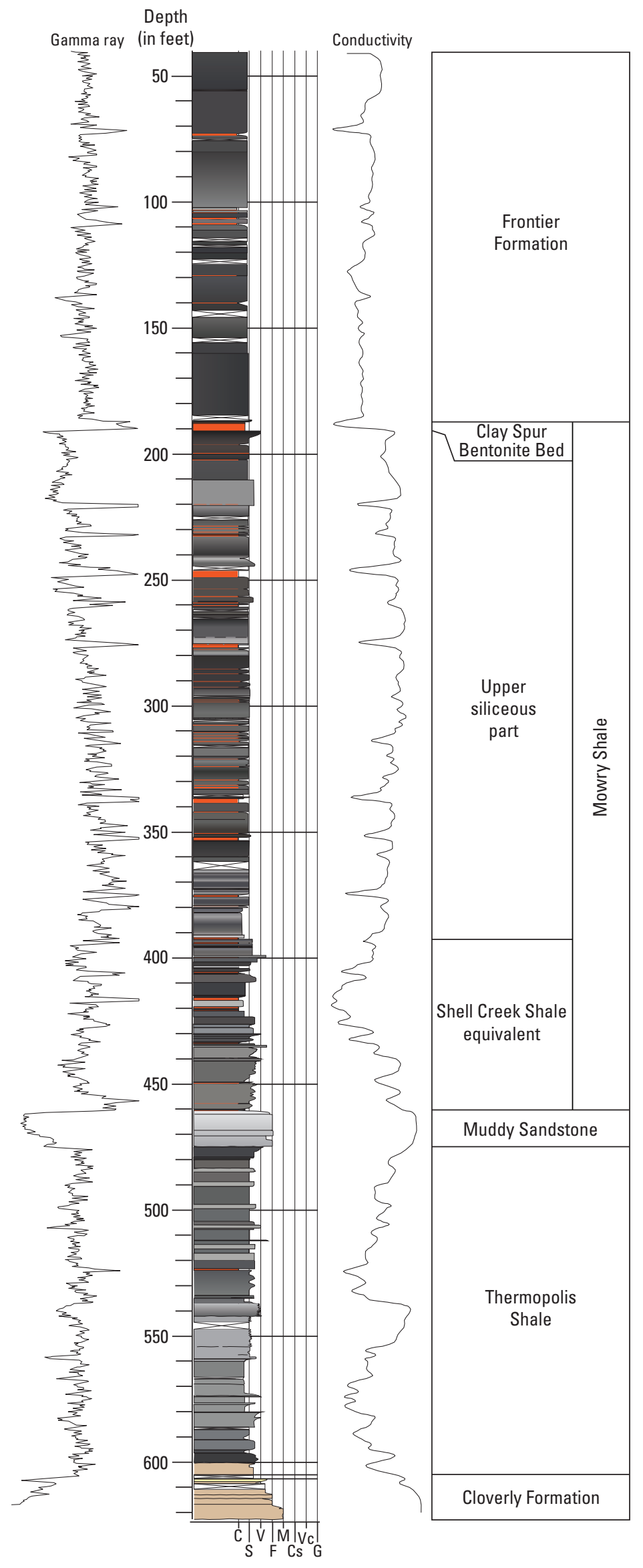




\section{Geophysical Logs}

Geophysical logs are shown in appendix 2, and the digital data are presented in Log ASCII Standard (LAS) format in Finn and others (2019a). The gamma ray and conductivity logs are paired with the lithologic log for points of comparison (fig. 4). Core-to-log comparisons that were noted include (1) the middle of an ash bed at $73 \mathrm{ft}$ in the core corresponds to about $72 \mathrm{ft}$ on the gamma and conductivity log; (2) the middle of a concretion at $138.4 \mathrm{ft}$ in the core corresponds to about $138 \mathrm{ft}$ on the gamma/conductivity log; (3) the middle of a concretion at $152.2 \mathrm{ft}$ in the core corresponds to about $153 \mathrm{ft}$ on the gamma log; and (4) the middle of an ash bed at $337.5 \mathrm{ft}$ in the core corresponds to about $336 \mathrm{ft}$ on the gamma $\log$. Therefore, the core-log correlation at any point is less than a $1.5 \mathrm{ft}$ difference. The geophysical logs of AR-1-13 have been correlated to nearby wells and formation contacts are mapped based on subsurface correlations (fig. 5).

\section{Stratigraphy}

The core includes the stratigraphic interval extending from the upper part of the Lower Cretaceous Cloverly Formation to the lower part of the Upper Cretaceous Frontier Formation (figs. 3 and 4). The formation contacts are picked at lithologic changes in the core and on the basis of subsurface correlations with nearby wells (fig. 5). In some cases, alternate contacts are discussed in the text and shown on the graphic log (appendix 1).

\section{Cloverly Formation}

The Cloverly Formation was named by Darton (1904) for outcrops on the east side of the Bighorn Basin. The age of the Cloverly is Early Cretaceous, probably Aptian and older (Merewether and others, 1997). Only the upper part of the Cloverly was cored in the well from $604.9 \mathrm{ft}$ to the bottom of the hole at $623 \mathrm{ft}$. The cored interval consists of fine- to medium-grained rippled to cross-laminated sandstone. There is minor greenish mudrock, mainly preserved as rip-up clasts at or just above erosional surfaces.

The contact with the overlying Thermopolis Shale is obscured in the core because of a lost interval, but is placed above a pyrite nodule and granule bed at $604.9 \mathrm{ft}$, below which is the missing interval and then another pyritized granule layer.

\section{Thermopolis Shale}

The Thermopolis Shale was originally named by Lupton (1916), which he separated into a lower shale unit, a middle "muddy sandstone" unit, and an upper shale unit. The history of the naming of the unit is well described by Eicher (1960, 1962). Later, in the Wind River Basin, Love (1948) formally referred to the lower shale unit as the Thermopolis Shale and the middle "muddy sandstones" as the Muddy Sandstone. Love (1948) included the upper shale unit with the overlying Mowry Shale. Sandstone beds in the lower shale have been referred to as the "rusty beds" by Washburne (1908) and Eicher (1962). The Thermopolis is Early Cretaceous Albian age based on the presence of diagnostic foraminifers in the upper part of the unit (Eicher, 1962); however, the lower part is barren of microfossils according to Eicher (1962) so that the lower age is indeterminate.

The Thermopolis is $130 \mathrm{ft}$ thick in the core and is present between 474.9 and $604.9 \mathrm{ft}$. The upper contact is somewhat uncertain but is picked based on the change from burrowed sandy siltstone below to convoluted sandstone above. The unit is primarily composed of dark-gray siltstone and sandy siltstone and contains numerous thin burrowed to laminated interbeds especially in the lower part of the unit, below $537.2 \mathrm{ft}$, which may be equivalent to the "rusty beds" of Eicher (1962). This unit is called the "silt marker" in some subsurface studies (Keefer, 1997; Keefer and Johnson, 1997). The laminated sandstone is mainly streaky to wavy lamination with erosional bases that are either storm or some other type of event beds. The beds are highly disrupted by burrows, mainly Planolites, and by sand-filled cracks, possibly of syneresis origin. There are numerous rusty brown concretions (see appendix 1, graphic $\log$ ), a prominent cone-in-cone structure at $558.5 \mathrm{ft}$, and one prominent altered volcanic ash between 523 and $524 \mathrm{ft}$.

\section{Muddy Sandstone}

The Thermopolis Shale is overlain by the Muddy Sandstone. The name Muddy was first used informally by drillers for "muddy sandstones" in the lower part of the Benton Shale as described in Hintze (1915) and was called the Muddy Sandstone by Love (1948). A reference section was designated in the Bighorn Basin by Eicher $(1960,1962)$ near Greybull, Wyoming. The age of the Muddy is Early Cretaceous based on the presence of Albian age foraminifera and ammonites in adjacent units (Eicher, 1962).

The contacts of the Muddy with underlying and overlying units are problematic because of gradational lithologies and the inability to see lateral continuity in a core. The lower contact is placed at $474.9 \mathrm{ft}$. There are several possibilities for the upper contact. The main lithostratigraphic contact is at $460.3 \mathrm{ft}$, at the top of a clean, well-sorted laminated to burrowed sandstone of probable nearshore marine origin. Log correlation to nearby wells supports this contact based on regional subsurface mapping (Finn, 2007b) (fig. 5). Using these picks, the Muddy is about $15 \mathrm{ft}$ thick. The dominant lithology is cross laminated to convoluted sandstone with minor siltstone laminations and distinct burrowing mainly by Skolithos. Cross lamination is from low angle to angle of repose. The low-angle beds are interpreted as hummocky cross stratification (hcs). The interpreted hcs, shows an overall decrease in radioactivity on the gamma log, and the wellsorted nature of the sandstone indicates a nearshore marine origin of the unit. Laterally in the subsurface (fig. 5), the 


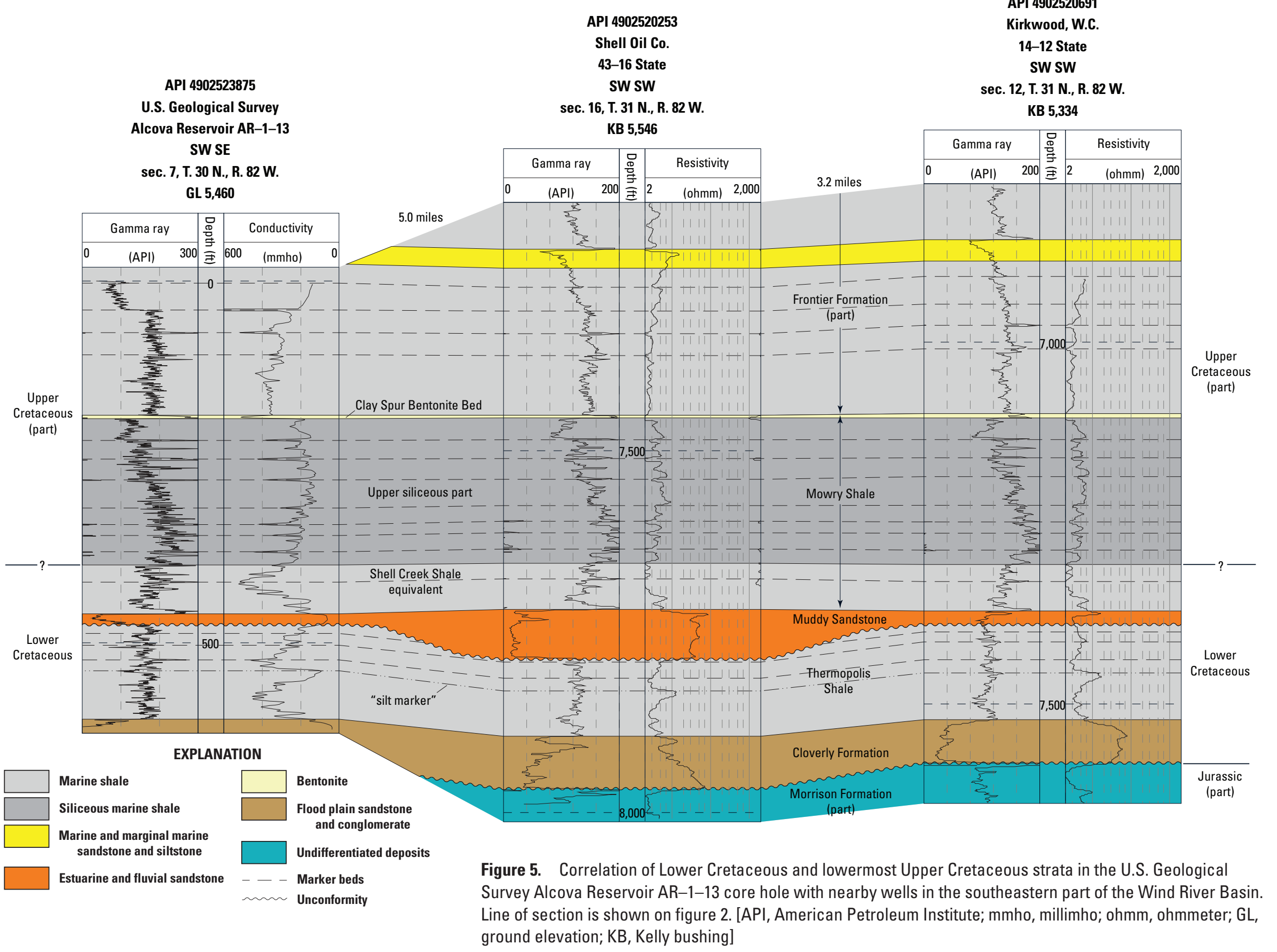


sandstone has a blocky fining upward trend that has historically been interpreted as an incised valley, filled with fluvial and estuarine deposits (Dolson and others, 1991) (fig. 5) and above that are landward-stepping nearshore marine deposits (Gustason, 1988).

Overlying the sandstone at $460.3 \mathrm{ft}$ is a thin $(0.1 \mathrm{ft})$ altered volcanic ash that displays high gamma measurements on the $\log$. This high gamma spike can be correlated with confidence in nearby wells (fig. 5).

The heterolithic strata between $429.9 \mathrm{ft}$ and $460.3 \mathrm{ft}$ are possibly of estuarine origin, or more likely are landwardstepping nearshore marine units associated with the underlying Muddy valley fill.

\section{Mowry Shale}

Darton (1904) named exposures of ridge-forming fossiliferous strata in the lower part of the Benton Group on the east side of the Bighorn Mountains, northwest of Buffalo, Wyoming, the Mowrie beds. In the Wind River Basin, the USGS referred to equivalent strata as the Mowry Shale (see for example, Love, 1948; Keefer, 1997; Keefer and Johnson, 1997; Finn, 2007b) (figs. 4 and 5). In the Wind River Basin, the Mowry extends from the Clay Spur Bentonite Bed down to the top of the Muddy Sandstone, and consists of two distinct units, a lower soft clay-rich shale (the upper Thermopolis shale unit of Lupton, 1916), and an upper hard brittle siliceous shale (Love, 1948; Keefer, 1997; Keefer and Johnson, 1997). Eicher $(1960,1962)$ named the lower part the Shell Creek Shale for exposures at Sheep Mountain anticline northwest of Greybull, Wyoming, in the Bighorn Basin. Eicher (1962, his fig. 8) traced the Shell Creek equivalent strata into three localities in the Wind River Basin, including the Alcova area. The Shell Creek contains two index fossils, a foraminifer Millammina manitobensis (Eicher, 1962) and an ammonite Neogastroplites hassi (Reeside and Cobban, 1960) that indicate an Albian age (Hancock and others, 1993, their table 1), but may be early Cenomanian age (Merewether and others, 2011, Merewether and McKinney, 2015) (fig. 3).

The Shell Creek extends from the top of the Muddy Sandstone upward to $392.35 \mathrm{ft}$ at the base of an altered volcanic ash bed, below which is a gray siltstone containing glauconite. Another possible contact is at $380.25 \mathrm{ft}$, below which is a mudrock interval containing numerous Inoceramus fragments. The interval between 392.35 and $460.3 \mathrm{ft}$ consists of a diverse set of mudrocks with Inoceramus fragments, glauconite, and burrows with some intervening thin rippled sandstone beds. There may be several shoreface units genetically related to backstepping Muddy Sandstone between 460.3 and $429.9 \mathrm{ft}$ where lenticular to wavylaminated sandstone is present with a highly diverse trace fossil assemblage dominated by Planolites, Teichichnus, and Chondrites, overlain by heavily burrowed mudrock. This interval is difficult to map in the subsurface so we include it in the Shell Creek.
The top of the Mowry Shale was originally defined from the Powder River Basin at the top of the Clay Spur Bentonite Bed (Ruby, 1930). The upper contact of the Mowry is straightforward and is placed at the top of the Clay Spur at $187.2 \mathrm{ft}$. This contact, somewhat disrupted by burrows of Teichichnus, matches the mapped contact in the subsurface. The Mowry contains all the early Cenomanian age ammonites of the genus Neogastropolites, except $N$. hassi (Reeside and Cobban, 1960; Cobban and Kennedy, 1989). The Clay Spur is present in the Wind River and adjacent basins and has been dated at about $97 \mathrm{Ma}$ (Obradovich, 1993).

The upper part of the Mowry is about $205 \mathrm{ft}$ thick using the lower contact of $392.35 \mathrm{ft}$ in the core hole. The lithology is mainly light- to dark-gray siltstone with numerous sandstone streaks and interbedded bentonite beds. Small sand-size rounded white specks and fish bone, teeth, and fish scales are present throughout the interval. The white specks are concentrated in siltstone portions of graded beds. A unique sandy interval exists just below the Clay Spur and is mappable in the eastern Wind River Basin, eastern Green River Basin, and onto the Casper arch. Below $380 \mathrm{ft}$, the facies consists of darkgray siltstone with abundant Inoceramus fragments that form discrete laminations instead of the sandstone streaks present in most of the upper part.

\section{Frontier Formation}

The Frontier Formation was named by Knight (1902) for exposures near the town of Frontier in western Wyoming. In the Wind River Basin, the name was first used by Hares (1916). The cored interval belongs to the Belle Fourche Member and is Cenomanian age based on ammonites found in the unit on outcrop (Merewether and Cobban, 2007).

The Frontier interval is from 40.5 to 187.2 or about $147 \mathrm{ft}$ thick representing the lower part of the member, because the core hole was spud in the unit. In the core, the main lithology is medium- to dark-gray siltstone and sandy siltstone with some interbedded burrowed or rippled sandstone streaks. There are two prominent altered volcanic ashes in the interval. The drill hole began in a sandstone that shows up on the gamma ray log, present from ground level to $40.5 \mathrm{ft}$.

\section{Geochemistry}

Thirty-nine samples were selected to evaluate the source rock potential of the marine shales in the cored interval as determined by total organic carbon (TOC) and programmed pyrolysis analyses. Five samples are from the Frontier Formation, 24 samples are from the upper siliceous part of the Mowry Shale, 4 samples are from the Shell Creek equivalent, and 6 samples are from the Thermopolis Shale (fig. 6). TOC content was determined using a LECO Corporation analyzer by the combustion method after carbonate removal (see Jarvie, 1991, for details), and the programmed pyrolysis analysis 
was completed using a HAWK Hydrocarbon Analyzer with Kinetics instrument (see Espitalie and others, 1977; Tissot and Welte, 1978; Peters, 1986; and Hunt, 1996, for detailed discussions of the pyrolysis method).

\section{Quantity of Organic Matter}

According to Jarvie (1991), the quantity of organic matter in a rock measured as weight percent TOC is an indicator of the organic richness and hydrocarbon generative potential. Rocks with less than 0.5 weight percent TOC have poor generative potential, rocks with 0.5 to 1 weight percent TOC are considered fair, rocks with 1-2 weight percent TOC are considered good, rocks with 2-4 weight percent TOC are considered very good, and rocks with greater than 4 weight percent TOC are considered to have excellent generative potential (Peters and Casa, 1994). TOC measurements for the Frontier Formation, the upper siliceous part of the Mowry Shale, the Shell Creek equivalent, and Thermopolis Shale are presented in table 1, figures 6 and 7, and Finn and others (2019a).

The five samples from the lower part of the Frontier Formation have TOC contents that range from 1.02 to 1.74 weight percent (average 1.54 weight percent), indicating good generative potential (fig. 7). TOC content for samples from the upper siliceous part of the Mowry Shale range from 1.04 to 4.53 weight percent, with an average of 2.87 weight percent (fig. 7). All but two samples have greater than 2 weight percent TOC indicating good to excellent generative potential. Samples from the lower part of the Mowry Shale (Shell Creek equivalent) have TOC contents that range from 0.63 to 1.22 weight percent (average 0.97 weight percent) indicating fair to good generative potential. TOC contents for the Thermopolis Shale samples range from 1.07 to 2.85 weight percent (average 1.62 weight percent), indicating good to very good generative potential.

Peters and Cassa (1994) suggest that TOC is not always a good indicator of source rock potential because measurements may include inert carbon that has little or no generating potential. Peters and Cassa (1994) stated that the $S_{2}$ measurement derived from pyrolysis analysis is a better indicator of generative potential of source rocks. The $\mathrm{S}_{2}$ value, expressed as milligrams of hydrocarbons per gram of rock, represents the fraction of original kerogen in a source rock capable of generating hydrocarbons that have not yet been converted to oil or gas or both (Tissot and Welte, 1978). According to Peters and Cassa (1994), rocks with $\mathrm{S}_{2}$ values less than 2.5 have poor generative potential, rocks with $\mathrm{S}_{2}$ values between 2.5 and 5 have fair generative potential, rocks with $S_{2}$ values ranging from 5 to 10 have good generative potential, rocks with $S_{2}$ values from 10 to 20 are considered to have very good generative potential, and rocks with $\mathrm{S}_{2}$ values greater than 20 have excellent generative potential. $S_{2}$ measurements for the Frontier Formation, upper part of the Mowry Shale, Shell Creek equivalent, and the Thermopolis Shale are presented in table 1 and shown in figures 6 and 7 .
Four of the five samples from the lower part of the Frontier Formation, have $\mathrm{S}_{2}$ values ranging from 2.5 to 2.65, indicating that the Frontier has fair generative potential (fig. 7). The remaining Frontier sample has poor potential with an $\mathrm{S}_{2}$ value near 1. The $\mathrm{S}_{2}$ values from the upper siliceous part of the Mowry Shale show a range from 1.88 to 21.09 (fig. 7) indicating good to excellent source rock. $\mathrm{S}_{2}$ values from the lower part of the Mowry Shale (Shell Creek equivalent) are less than 1.0 and are considered to have poor potential for generating hydrocarbons (fig. 7). Three of the six samples from the Thermopolis Shale have $\mathrm{S}_{2}$ values ranging from 2.59 to 4.52 indicating a fair potential to generate hydrocarbons. The remaining three samples have values less than 2.5 and are considered poor source rocks (fig. 7).

\section{Types of Organic Matter}

According to Jacobson (1991) and Peters and Cassa (1994), there are four main types of kerogen in sedimentary rocks: Type I, composed of oil-prone hydrogen-rich organic matter is generally from lacustrine and some marine sediments; Type II, also composed of oil-prone hydrogen-rich organic matter that is mainly in marine sediments; Type III, composed of terrestrial organic matter derived mainly from woody plant material that is low in hydrogen content and generates mainly gas; and Type IV, composed of dead or inert carbon that has little or no generating capacity. Using the results of pyrolysis analysis, the type of kerogen present in a source rock can be determined by the hydrogen index and the oxygen index, defined as $\left(\mathrm{S}_{2} / \mathrm{TOC}\right) \times 100(\mathrm{mg}-\mathrm{HC} / \mathrm{g}-\mathrm{TOC})$, and $\left(\mathrm{S}_{3} / \mathrm{TOC}\right) \times 100\left(\mathrm{mg}-\mathrm{CO}_{2} / \mathrm{g}-\mathrm{TOC}\right)$, respectively (Espitalie and others, 1977; Tissot and Welte, 1978; and Hunt, 1996). According to Hunt (1996), the type of hydrocarbons (oil or gas) generated from a source rock depends on the hydrogen content of the organic matter. The results from pyrolysis analysis of the samples collected for the lower part of the Frontier Formation, upper part of the Mowry Shale, Shell Creek equivalent, and the Thermopolis Shale are shown on table 1 and plotted in figures 6 and 8 .

The five samples from the lower part of the Frontier Formation indicate that it is composed of Type III gas-prone kerogen (fig. 8). All but one sample from the upper siliceous part of the Mowry Shale indicate that it is composed of Type II oil-prone kerogen with lesser amounts of mixed Type II/III kerogen (fig. 8). Three samples from the lower part of the Mowry Shale (Shell Creek equivalent) are composed of Type IV kerogen with little or no generative potential (fig. 8). The remaining sample from the Shell Creek is marginal Type III with some capacity to generate gas. Results from the Thermopolis Shale show it is composed mainly of Type III and Type IV kerogen with some mixed Type II/III kerogen indicating that it is a potential source rock mainly for gas and marginal for oil (fig. 8). 
Table 1. Total organic carbon and pyrolysis data for the U.S. Geological Survey Alcova Reservoir AR-1-13 core hole, American Petroleum Institute well 4902523875, latitude 42.575145, longitude 106.70383, Township 30 N., Range 82 W., sec. 7, SW1/4, SE1/4, Sixth Principal Meridian, Elevation 5,460 feet.

[Depths are in feet; Tmax, temperature $\left({ }^{\circ} \mathrm{C}\right.$ [degrees Celsius]) corresponding to $\mathrm{S}_{2}$ peak; $\mathrm{S}_{1}$, milligrams of hydrocarbons per gram of rock; $\mathrm{S}_{2}$, milligrams of hydrocarbons per gram of rock; $\mathrm{S}_{3}$, milligrams of carbon dioxide $\left(\mathrm{CO}_{2}\right)$ per gram of rock; PI, production index $\left[\mathrm{S}_{1} / \mathrm{S}_{1}+\mathrm{S}_{2}\right]$; TOC, total organic carbon in weight percent; TC, total carbon in weight percent; HI, hydrogen index; OI, oxygen index]

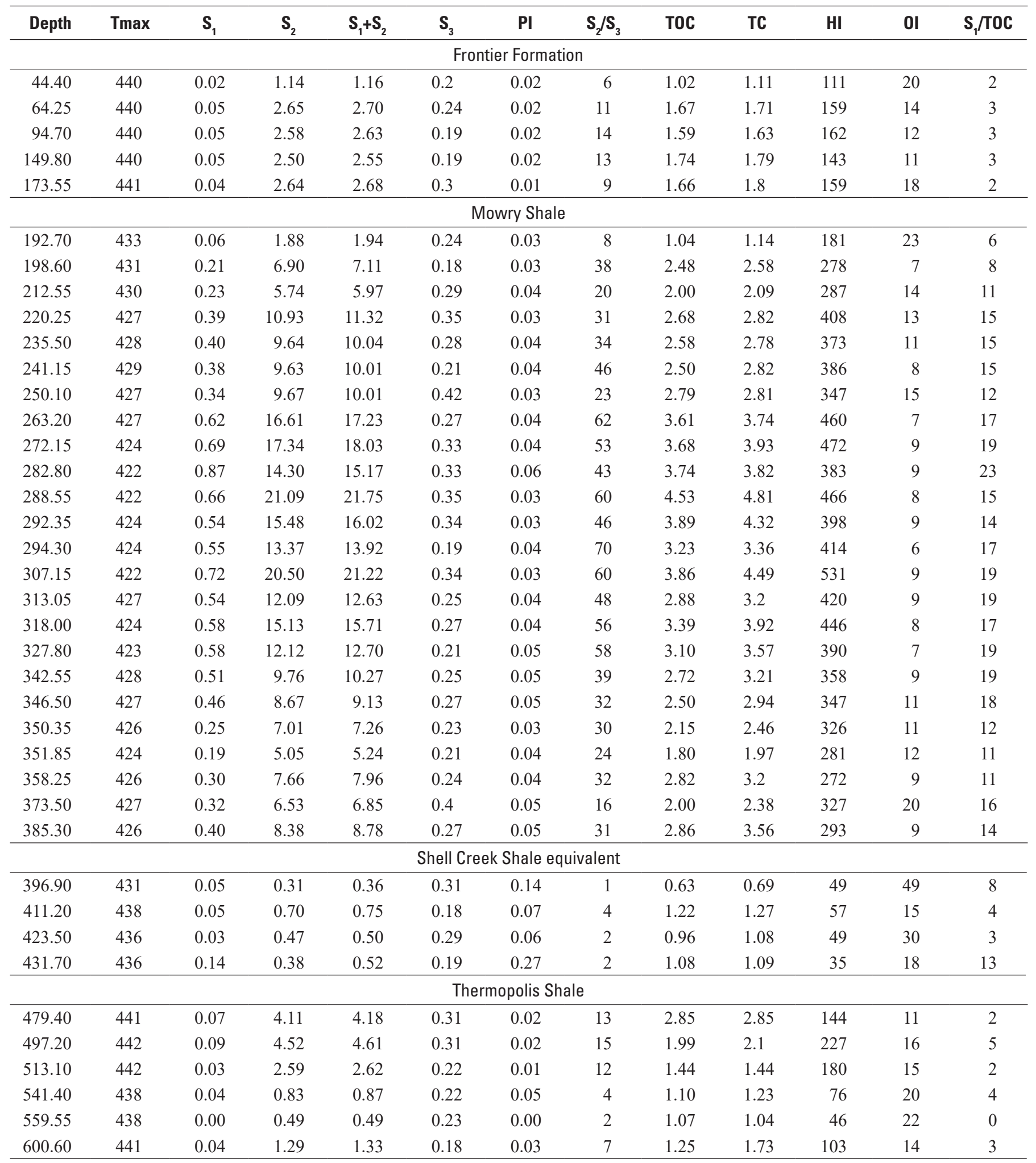


API 4902523875

U.S.G.S

Alcova Reservoir AR-1-13

SW SE

sec. 7, T. 30 N., R. 82 W.

GL 5,460

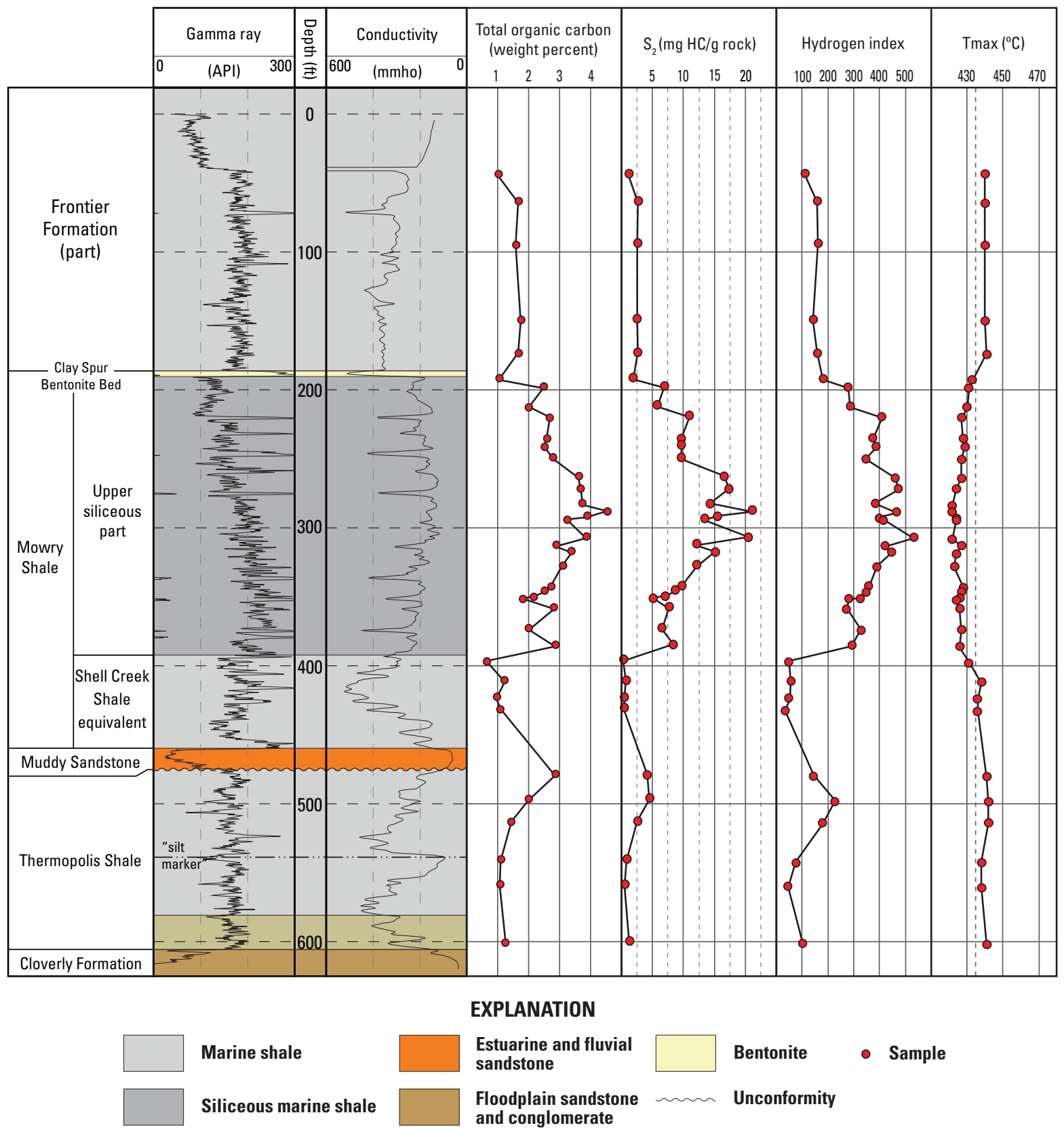

Figure 6. U.S. Geological Survey Alcova Reservoir AR-1-13 core hole showing relation of stratigraphic intervals to organic richness and kerogen type. [API, American Petroleum Institute units; mmho, millimho; mg HC/g rock, milligrams of hydrocarbons per gram of rock; ${ }^{\circ} \mathrm{C}$, degrees Celsius] 


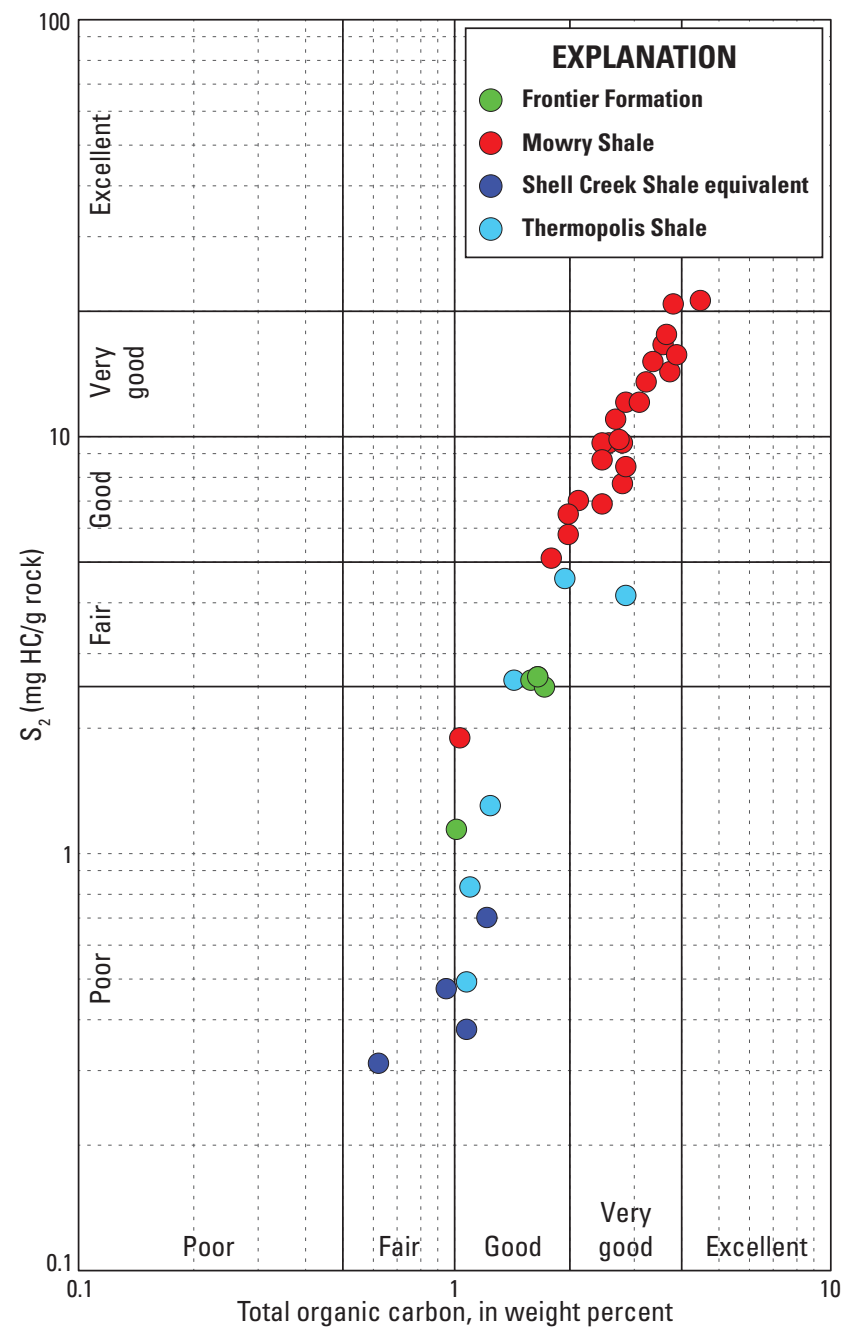

Figure 7. Cross plot of $\mathrm{S}_{2}$ and total organic carbon for samples from the U.S. Geological Survey Alcova Reservoir AR-1-13 core hole. Parameters describing source rock generative potential are from Peters and Cassa (1994). [mg HC/g rock, milligrams of hydrocarbons per gram of rock]

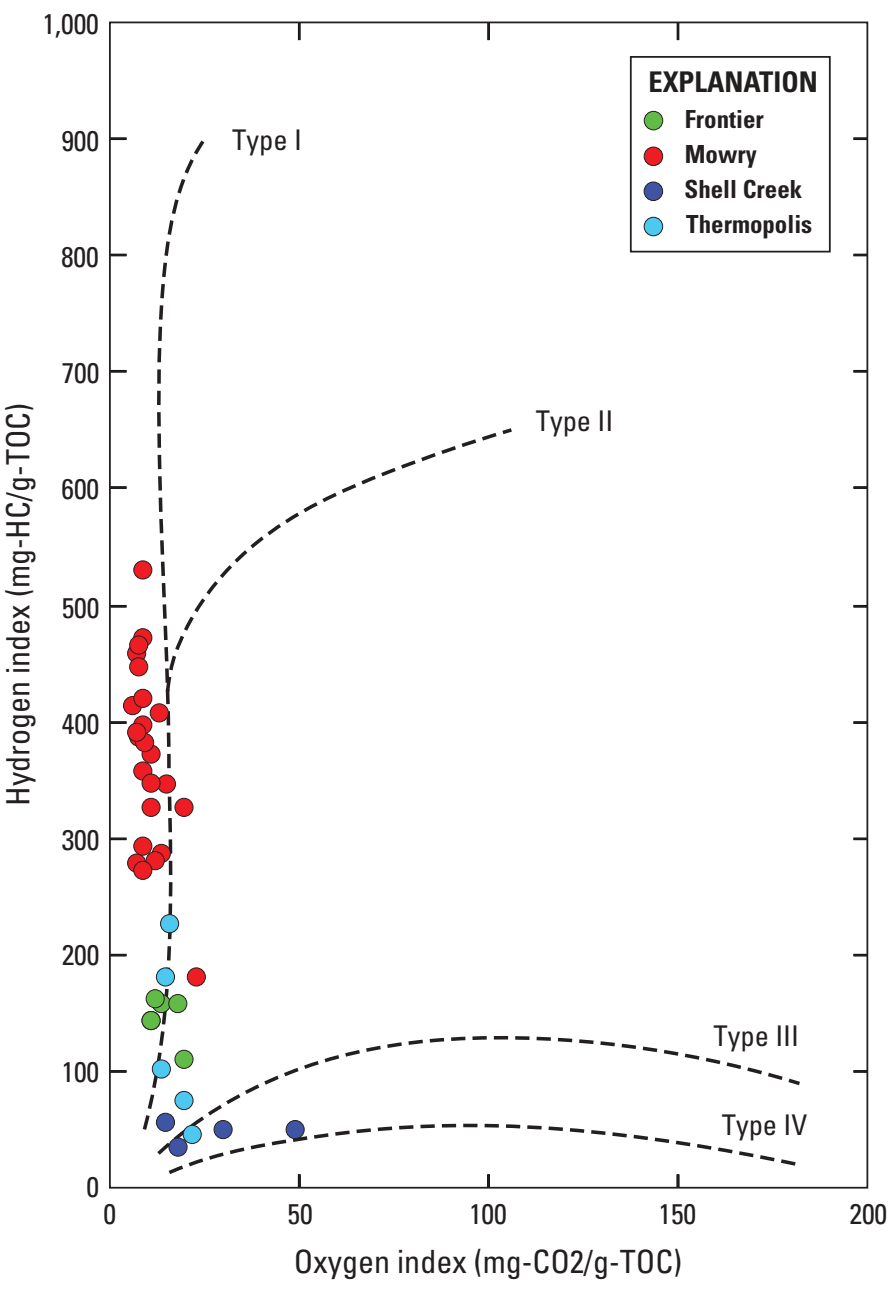

Figure 8. Cross plot of hydrogen index and oxygen index for samples from the U.S. Geological Survey Alcova Reservoir AR-1-13 core hole. [mg-HC/g-TOC, milligrams of hydrocarbons per gram of total organic carbon; $\mathrm{mg}-\mathrm{CO}_{2} / \mathrm{g}-\mathrm{TOC}$, milligrams of carbon dioxide per gram of total organic carbon] 


\section{Geochemistry Summary}

Results of total organic carbon and programmed pyrolysis analyses of potential hydrocarbon source rocks in the Alcova Reservoir AR-1-13 core hole in Natrona County, Wyoming, in the southeastern part of the Wind River Basin are summarized as follows:

1. The lower part of the Frontier Formation contains Type III gas-prone kerogen, with poor to fair generative potential.

2. The upper part of the Mowry Shale has good to excellent generative potential, with organic matter composed mainly of Type II oil-prone kerogen with some mixed Type II/III kerogen capable of generating oil and gas.

3. The kerogen in the Shell Creek equivalent is marginal Type III and mainly Type IV kerogen with poor generative potential.

4. The Thermopolis Shale has poor to fair generative potential, with mainly Type III gas-prone kerogen.

\section{Acknowledgments}

The authors thank the U.S. Geological Survey (USGS) drilling group, especially Art Clark, the staff of the USGS Core Research Center including John Rhoades, Terry Huber, Dawn Ivis, and Josh Hicks; and the staff of the Central Energy Resources Science Center Petroleum Geochemistry Research Laboratory including Augusta Warden, Mark Dreier, and Tom Oliver. The manuscript benefitted from reviews by Ron Johnson, Justin Birdwell, and Ofori Pearson of the USGS and their suggestions and comments are greatly appreciated.

\section{References Cited}

Burtner, R.L., and Warner, M.A., 1984, Hydrocarbon generation in Lower Cretaceous Mowry and Skull Creek Shales of the northern Rocky Mountain area, in Woodward, J., Meissner, F.F., and Clayton, J.L., eds., Hydrocarbon source rocks of the greater Rocky Mountain region: Rocky Mountain Association of Geologists Guidebook, p. 449-467.

Cobban, W.A., and Kennedy, W.J., 1989, The ammonite Metengonoceras Hyatt, 1903, from the Mowry Shale (Cretaceous) of Montana and Wyoming: U.S. Geological Survey Bulletin 1787-L, 11 p.

Darton, N.H., 1904, Comparison of the stratigraphy of the Black Hills, Bighorn Mountains, and Rocky Mountain Front Range: Geological Society of America Bulletin, v. 15 , p. $379-448$.
Dolson, J., Muller, D., Evetts, M.J., and Stein, J.A., 1991, Regional paleotopographic trends and production, Muddy Sandstone (Lower Cretaceous), central and northern Rocky Mountains: American Association of Petroleum Geologists Bulletin v. 75, no. 3 p. 409-435.

Eicher, D.L., 1960, Stratigraphy and micropaleontology of the Thermopolis Shale: Peabody Museum of Natural History, Yale University, Bulletin 15, 126 p.

Eicher, D.L., 1962, Biostratigraphy of the Thermopolis, Muddy, and Shell Creek Formations, in Enyert, R.L., and Curry, W.H., eds., Symposium on Early Cretaceous rocks of Wyoming and adjacent areas: Wyoming Geological Association 17th Annual Field Conference Guidebook, p. 72-93.

Espitalie, J., Madec, J.M., Tissot, B., Mennig, J.J., and Leplat, P., 1977, Source rock characterization method for petroleum exploration: Offshore Technology Conference, v. 3, no. 9, p. 439-444.

Finn, T.M., 2007a, Source rock potential of Upper Cretaceous marine shales in the Wind River Basin, Wyoming, in USGS Wind River Basin Province Assessment Team, Petroleum systems and geologic assessment of oil and gas in the Wind River Basin Province, Wyoming: U.S. Geological Survey Digital Data Series DDS-69-J, ch. 8, 24 p.

Finn, T.M., 2007b, Subsurface stratigraphic cross sections of Cretaceous and lower Tertiary rocks in the Wind River Basin, central Wyoming, in USGS Wind River Basin Assessment Team, Petroleum systems and geologic assessment of oil and gas resources in the Wind River Basin Province, Wyoming: U.S. Geological Survey Digital Data Series DDS-69-J, ch. 9, 28 p.

Finn, T.M., 2019, Structure contour and overburden maps of the Niobrara interval of the Upper Cretaceous Cody Shale in the Wind River Basin, Wyoming: U.S. Geological Survey Scientific Investigations Map 3427, pamphlet 9 p., 2 sheets, scale 1:500,000, accessed March 2019, at https://doi.org/10.3133/sim3427.

Finn, T.M., Kirschbaum, M.A., and Schenk, C.J., 2019a, LAS digital data files for the U.S. Geological Survey Alcova AR-1-13 core hole, Natrona County, Wyoming: U.S. Geological Survey data release, https://doi.org/10.5066/P9J7FJQU.

Finn, T.M., Kirschbaum, M.A., and Schenk, C.J., 2019b, Total organic carbon and pyrolysis analysis data for the U.S. Geological Survey Alcova AR-1-13 core hole, Natrona County, Wyoming (ver. 1.1, November 2021): U.S. Geological Survey data release, https://doi.org/10.5066/P9VLAKVG.

Gustason, E.R., 1988, Depositional and tectonic history of the Lower Cretaceous Muddy Sandstone, Lazy B Field, Powder River Basin, Wyoming in Diedrich, R.P., Dyka, M.A.K., Miller, W.R. eds., Eastern Powder River Basin-Black Hills: Wyoming Geological Association 39th Annual Field Conference, p. 129-146. 
Hancock, J.M., Kennedy, W.J., and Cobban, W.A., 1993, A correlation of upper Albian to basal Coniacian sequences of northwest Europe, Texas and the United States Western Interior, in Caldwell, W.G.E., and Kauffman, E.G., eds., Evolution of the Western Interior Basin: Geological Association of Canada Special Paper 39, p. 453-476.

Hares, C.J., 1916, Anticlines in central Wyoming: U.S. Geological Survey Bulletin 641-I, p. 233-279.

Hintze, F.F., 1915, The Basin and Greybull oil and gas fields: Wyoming Geological Survey Bulletin 10, 62 p.

Hunt, J.M., 1996, Petroleum geochemistry and geology: New York, W.H. Freeman and Company, 743 p.

Jacobson, S.R., 1991, Petroleum source rocks and organic facies, in Merrill, R.K., ed., Source and migration processes and evaluation techniques: American Association of Petroleum Geologists Handbook of Petroleum Geology, p. 1-11.

Jarvie, D.M., 1991, Total organic carbon (TOC) analysis, in Merrill, R.K., ed., Source and migration processes and evaluation techniques: American Association of Petroleum Geologists Handbook of Petroleum Geology, p. 113-118.

Johnson, R.C., Finn, T.M., Kirschbaum, M.A., Roberts, S.B., Roberts, L.N.R., Cook, Troy, and Taylor, D.J, 2007, The Cretaceous-Lower Tertiary Composite Total Petroleum System, Wind River Basin, Wyoming in USGS Wind River Basin Province Assessment Team, Petroleum systems and geologic assessment of oil and gas in the Wind River Basin Province, Wyoming: U.S. Geological Survey Digital Data Series DDS-69-J, ch. 4, DDS-69-J, 96 p.

Keefer, W.R., 1997, Stratigraphy and correlation of Cretaceous and Paleocene rocks, northern Wind River Basin, Wyoming: U.S. Geological Survey Oil and Gas Investigations Chart OC-146-A.

Keefer, W.R., and Johnson, R.C., 1997, Stratigraphy and correlation of Cretaceous and Paleocene rocks, west-central Wind River Basin, Wyoming: U.S. Geological Survey Oil and Gas Investigations Chart OC-146-B.

Kirschbaum, M.A., Finn T.M., Johnson, R.C., Kibler, J., Lillis, P.G., Nelson, P.H., Roberts, L.N.R., Roberts, S.B., Charpentier, R.R, Cook, T., Klett, T.R., Pollastro, R.M., and Schenk, C.J., 2005, Assessment of undiscovered oil and gas resources of the Wind River Basin Province: U.S. Geological Survey Fact Sheet FS-2005-3141, 2 p.

Knight, W.C., 1902, The petroleum fields of Wyoming-III: Engineering and Mining Journal, v. 73, no. 21, p. 720-723.

Love, J.D., 1948, Mesozoic stratigraphy of the Wind River Basin, central Wyoming in Maebius, J.B., and Netterstrom, P.W., eds., Wind River Basin, Wyoming: Wyoming Geological Association 3rd Annual Field Conference, p. 96-111.

Lupton, C.T., 1916, Oil and gas near Basin, Big Horn County, Wyoming: U.S. Geological Survey Bulletin 621, p. 157-190.
Merewether, E.A., Dolson, J.C., Hanson, W.B., Keefer, W.R., Law, B.E., Mueller, R.E., Ryer, T.A., Smith, A.C., Stilwell, D.P., and Wheeler, D.M., 1997, Cretaceous stratigraphy in a northeast-trending transect, northern Utah to southcentral South Dakota: U.S. Geological Survey Map I-2609, 2 sheets, pamphlet, $10 \mathrm{p}$.

Merewether, E.A., and Cobban, W.A., 2007, Outcrop descriptions and fossils from the Upper Cretaceous Frontier Formation, Wind River Basin and adjacent areas, Wyoming, in U.S. Geological Survey Wind River Basin Assessment Team, eds., Petroleum systems and geologic assessment of oil and gas resources in the Wind River Basin Province, Wyoming: U.S. Geological Survey Digital Data Series DDS-69-J, Chapter 11, 95 p.

Merewether, E.A., Cobban, W.A., and Obradovich, J.D., 2011, Biostratigraphic data from Upper Cretaceous Formationeastern Wyoming, central Colorado, and northeastern New Mexico: U.S. Geological Survey Scientific Investigations Map 3175, 2 sheets, pamphlet, $10 \mathrm{p}$.

Merewether, E.A., and McKinney, K.C., 2015, Chronostratigraphic cross section of Cretaceous formations in western Montana, western Wyoming, eastern Utah, northeastern Arizona, and northwestern New Mexico, U.S.A.: U.S. Geological Survey Open-File Report 2015-1087, 10 p., 1 sheet, accessed February 2018, at https://dx.doi.org/10.3133/ ofr20151087.

Obradovich, J.D., 1993, A Cretaceous time scale, in Caldwell, W.G.E., and Kauffman, E.G., eds., Evolution of the Western Interior Basin: Geological Association of Canada Special Paper 39, p. 379-396.

Peters, K.E., 1986, Guidelines for evaluating petroleum source rock using programmed pyrolysis: American Association of Petroleum Geologists Bulletin, v. 70, no. 3, p. 318-329.

Peters, K.E., and Cassa, M.R., 1994, Applied source rock geochemistry, in Magoon, L.B., and Dow, W.G., eds., The petroleum system-From source to trap: American Association of Petroleum Geologists Memoir 60, p. 93-120.

Reeside, J.B., Jr., and Cobban, W.A., 1960, Studies of the Mowry Shale (Cretaceous) and contemporary formations in the United States and Canada: U.S. Geological Survey Professional Paper 355, $126 \mathrm{p}$.

Ruby, W.W., 1930, Lithologic studies of the fine-grained Upper Cretaceous sedimentary rocks of the Black Hills region: U.S. Geological Survey Professional Paper 165, 54 p.

Tissot, B.P., and Welte, D.H., 1978, Petroleum formation and occurrence: New York, Springer-Verlag, 538 p.

Washburne, C.W., 1908, Gas fields of the Bighorn Basin, Wyoming: U.S. Geological Survey Bulletin 340-F, p. 348-363. 
Appendix 1. Detailed Core Descriptions of the USGS AR-1-13 Core Hole, Natrona County, Wyoming 


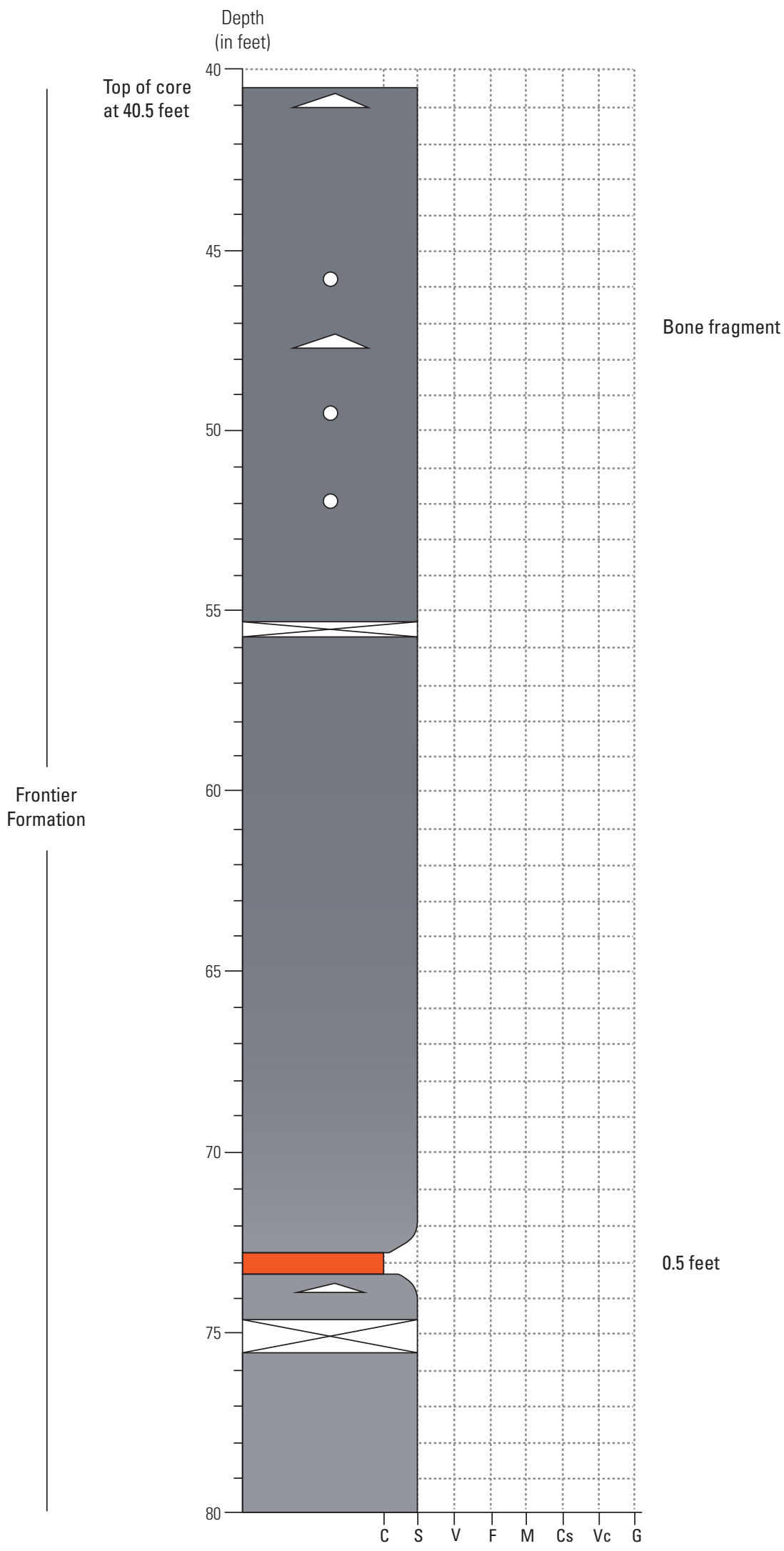




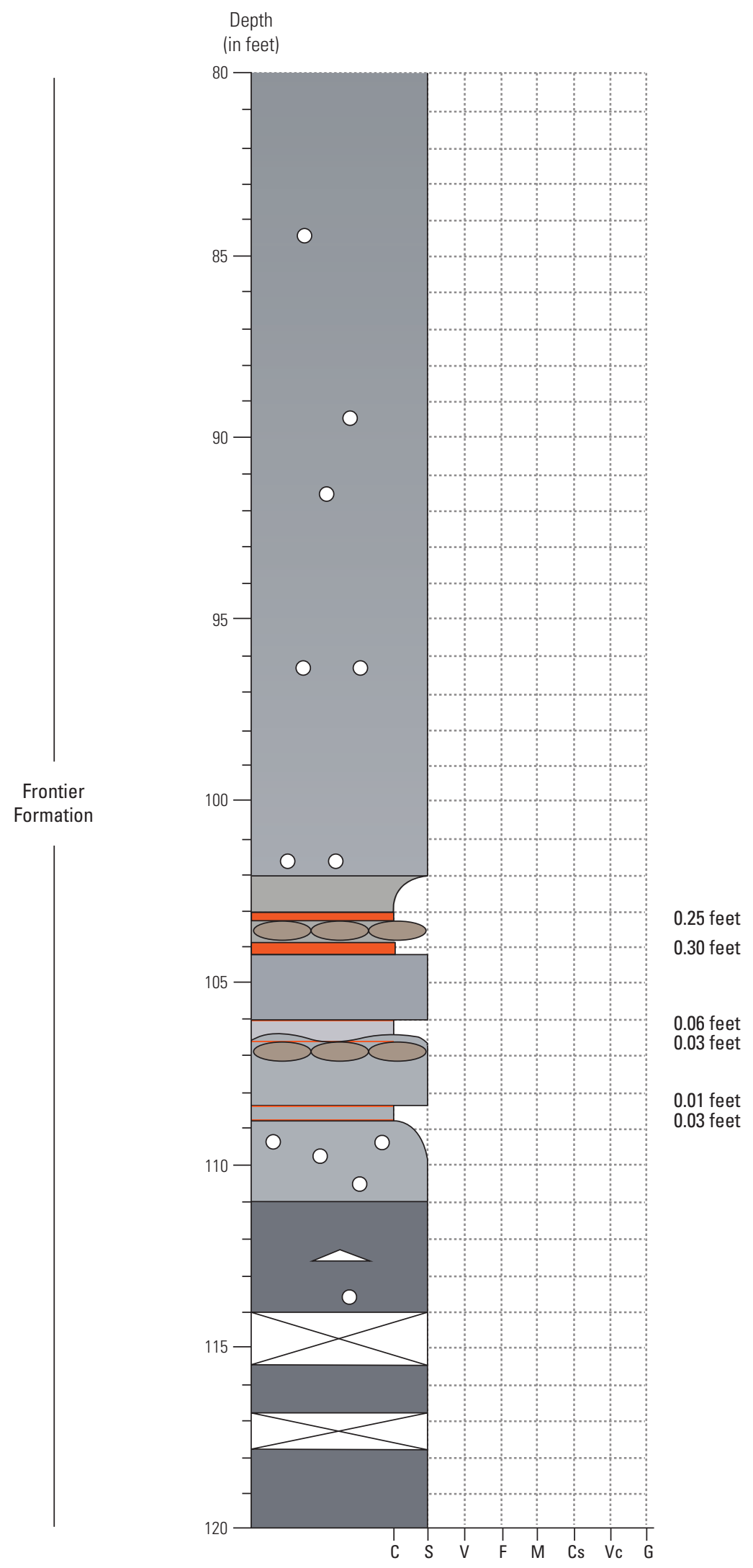




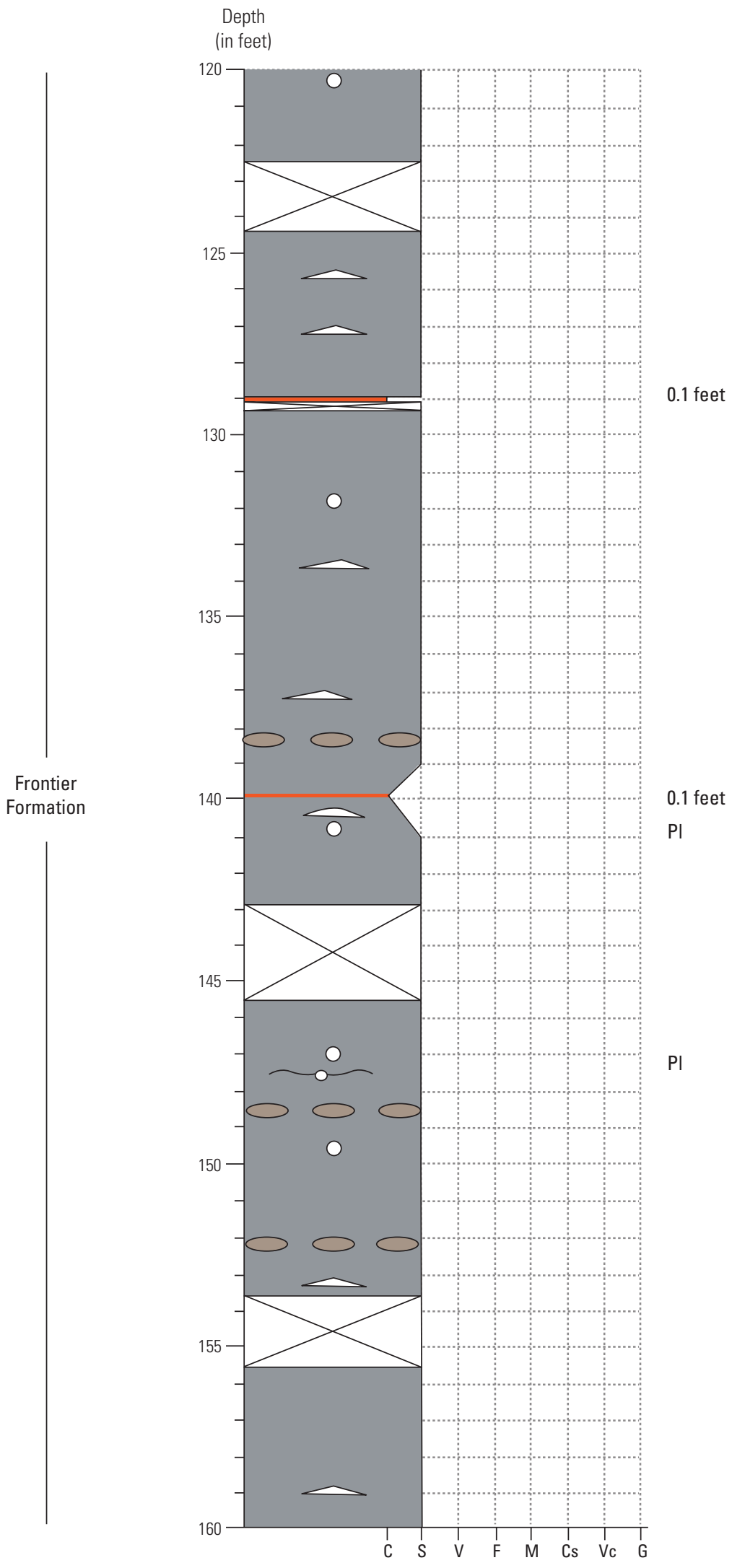




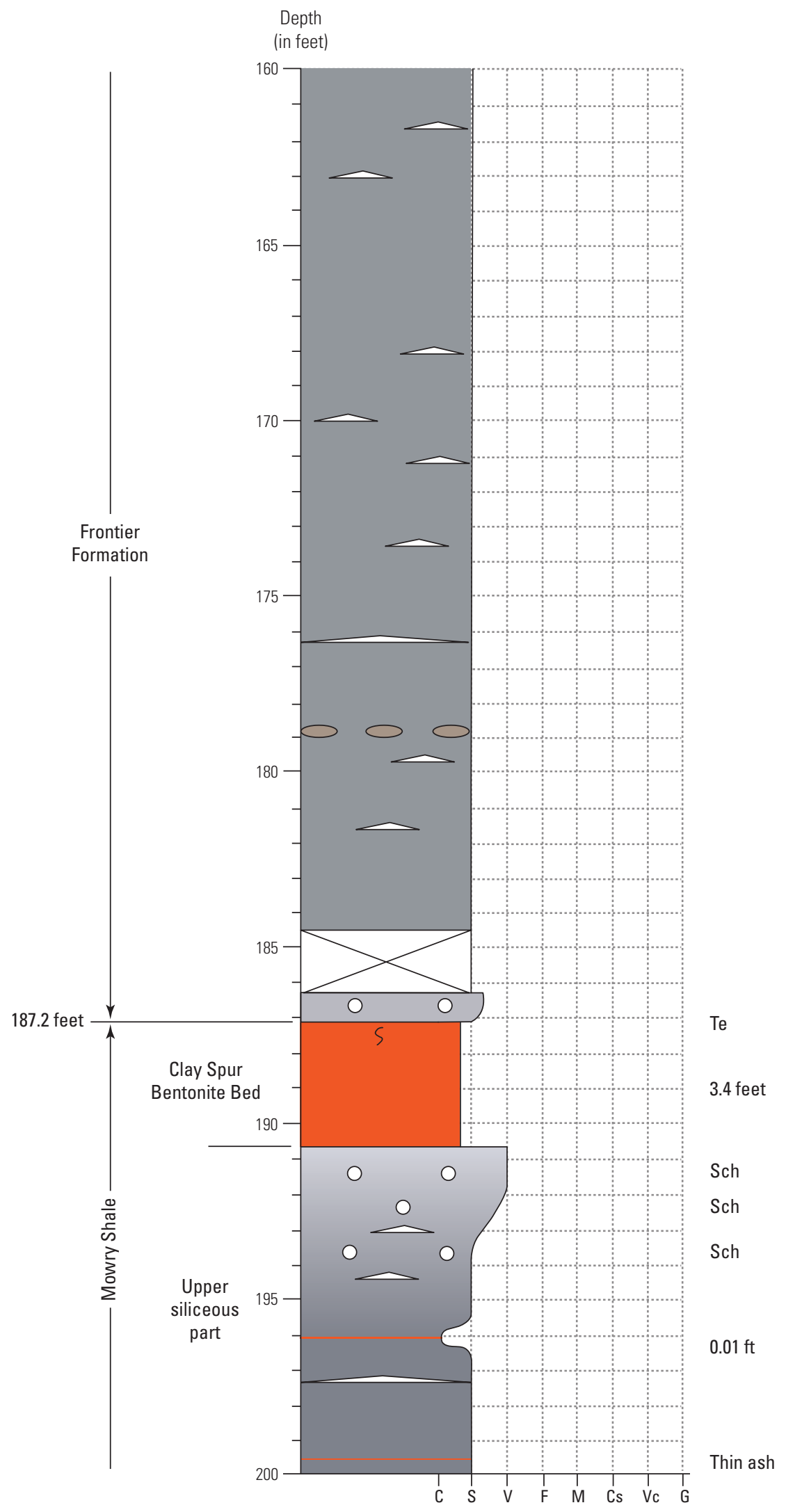




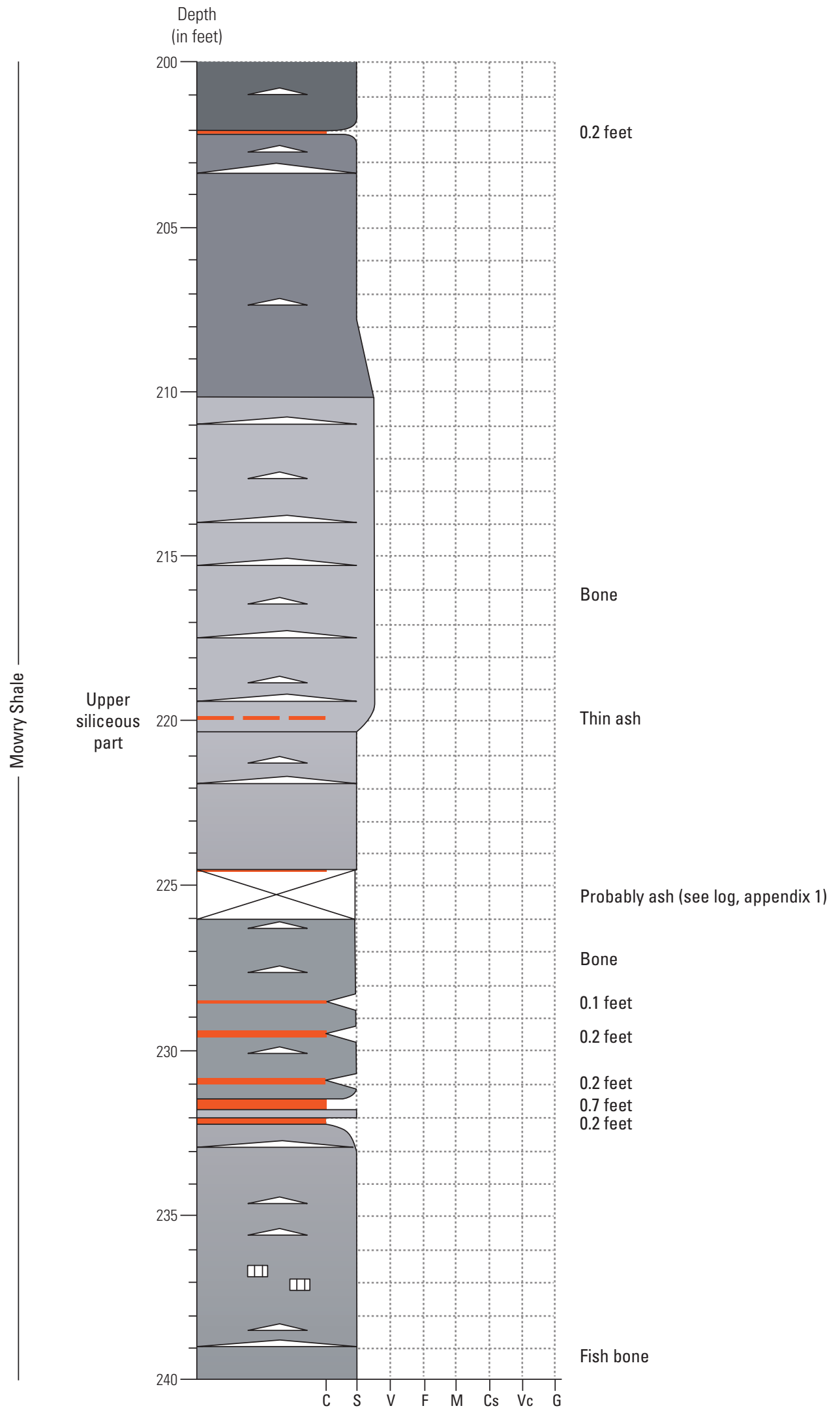




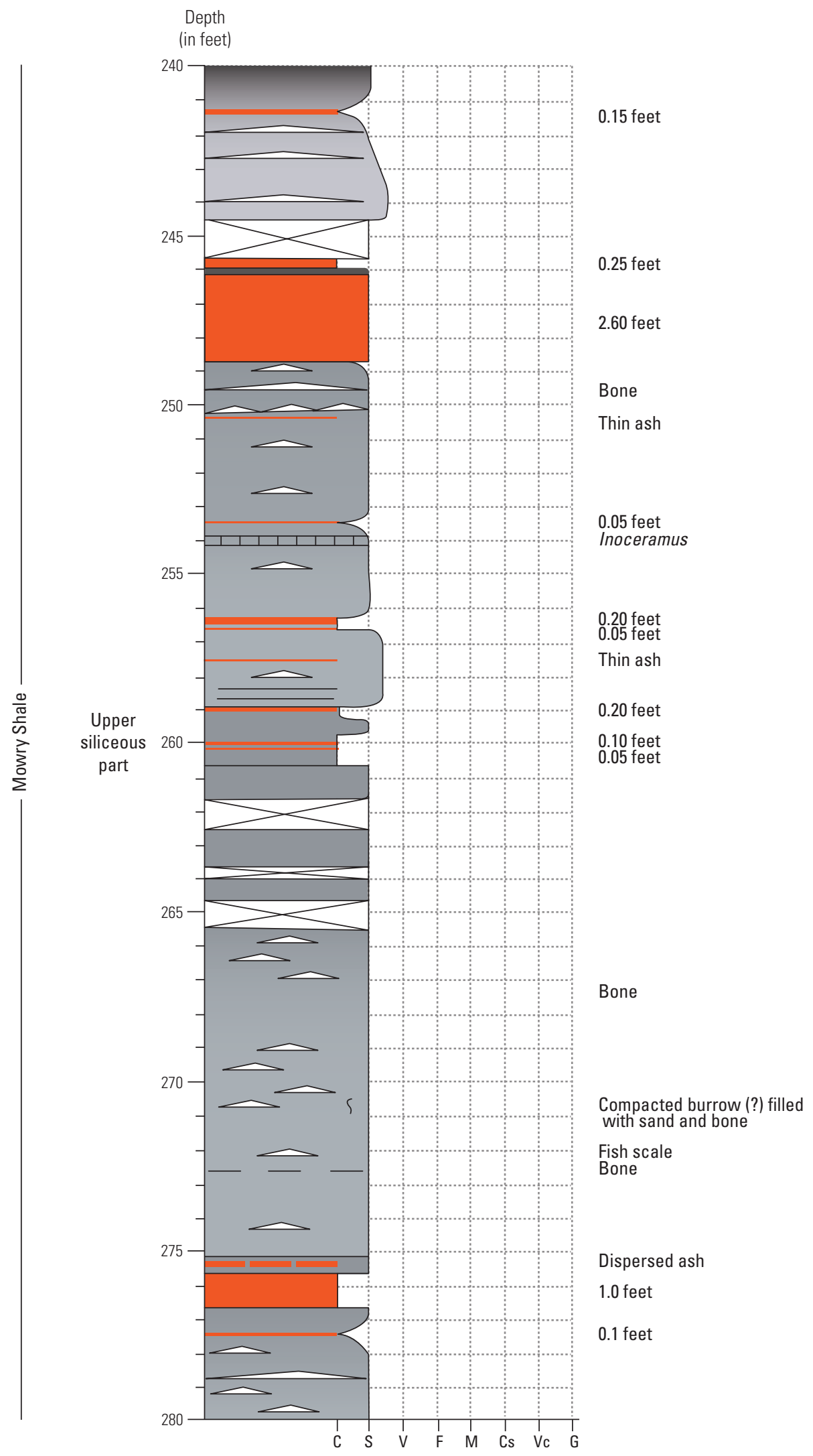




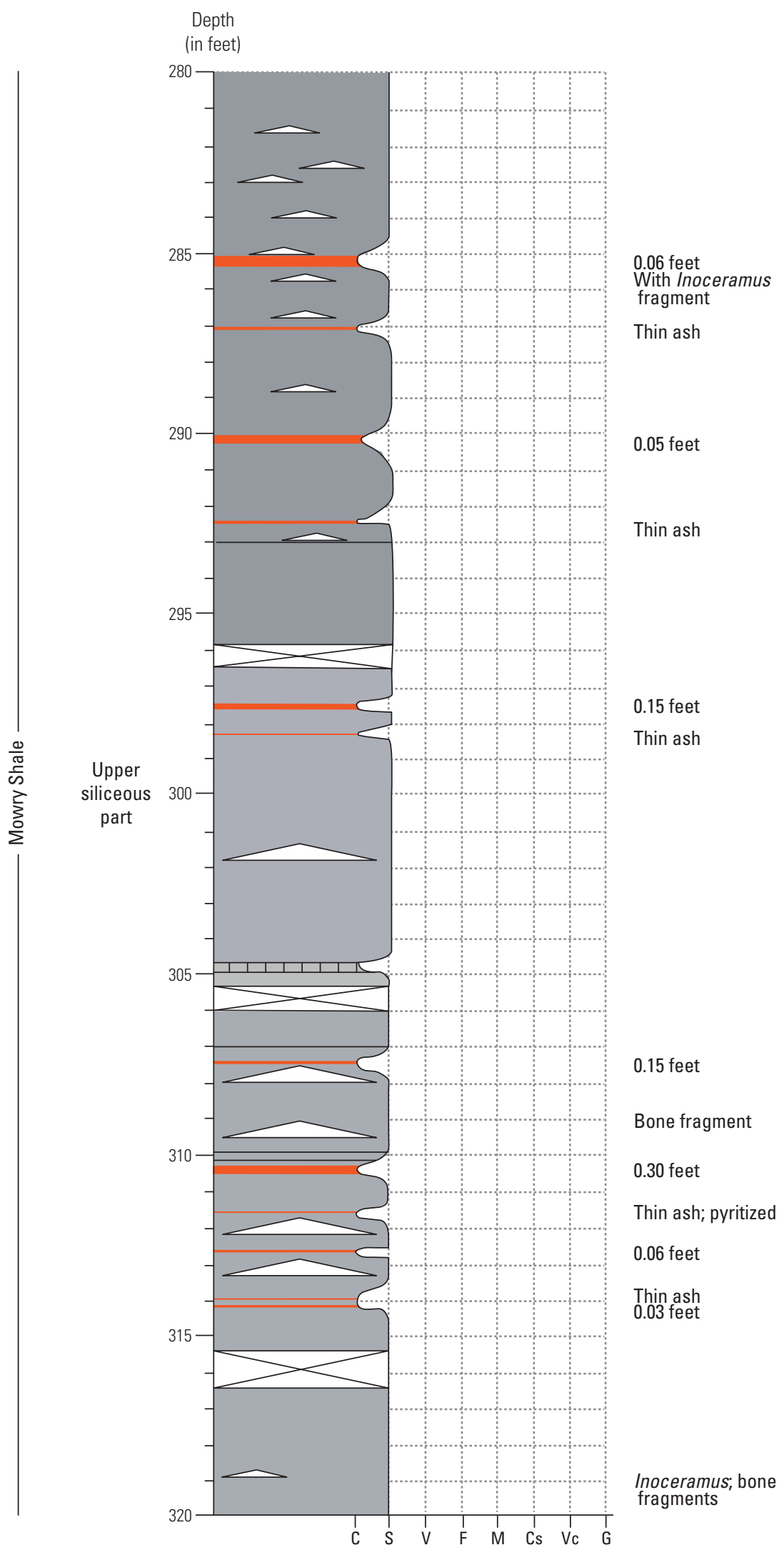




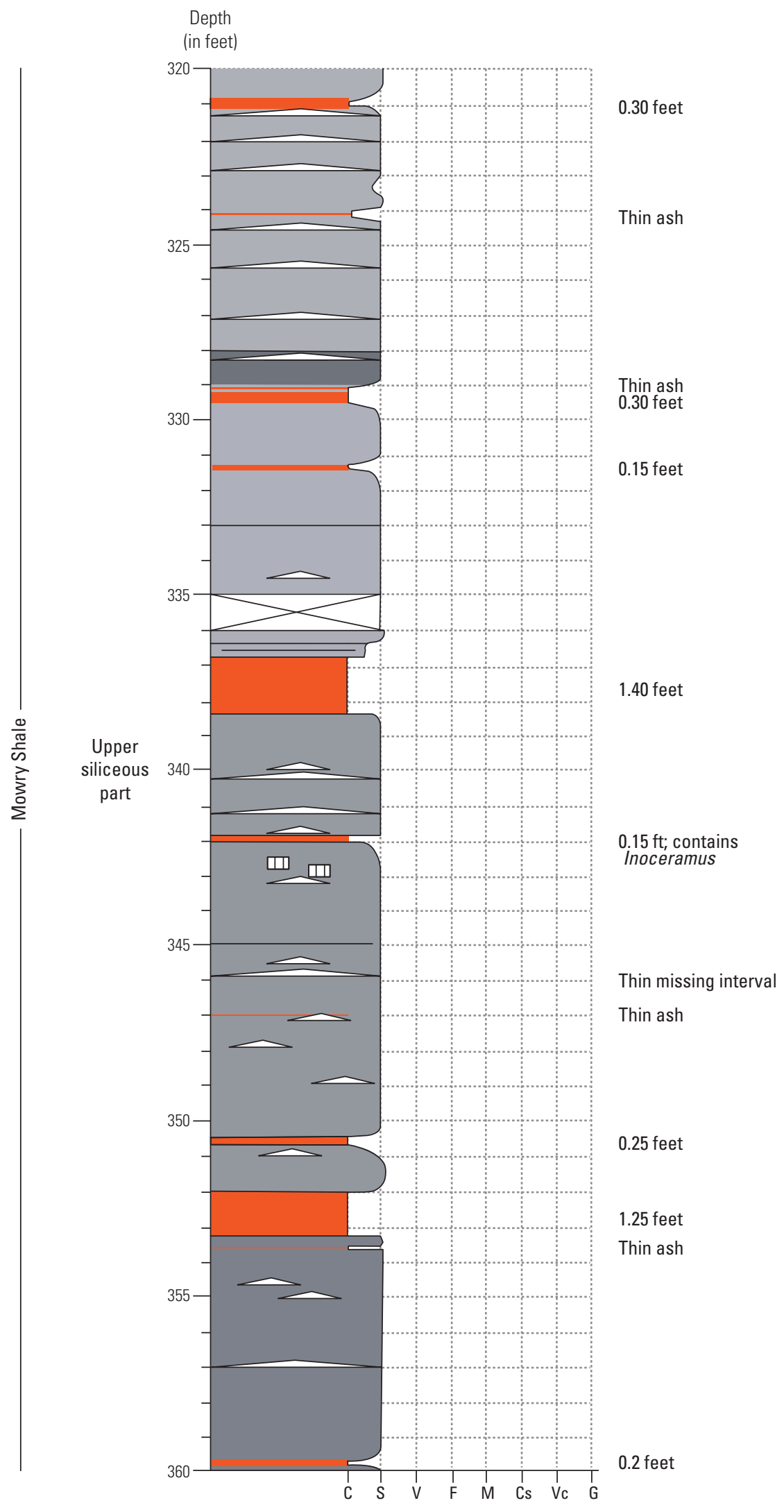




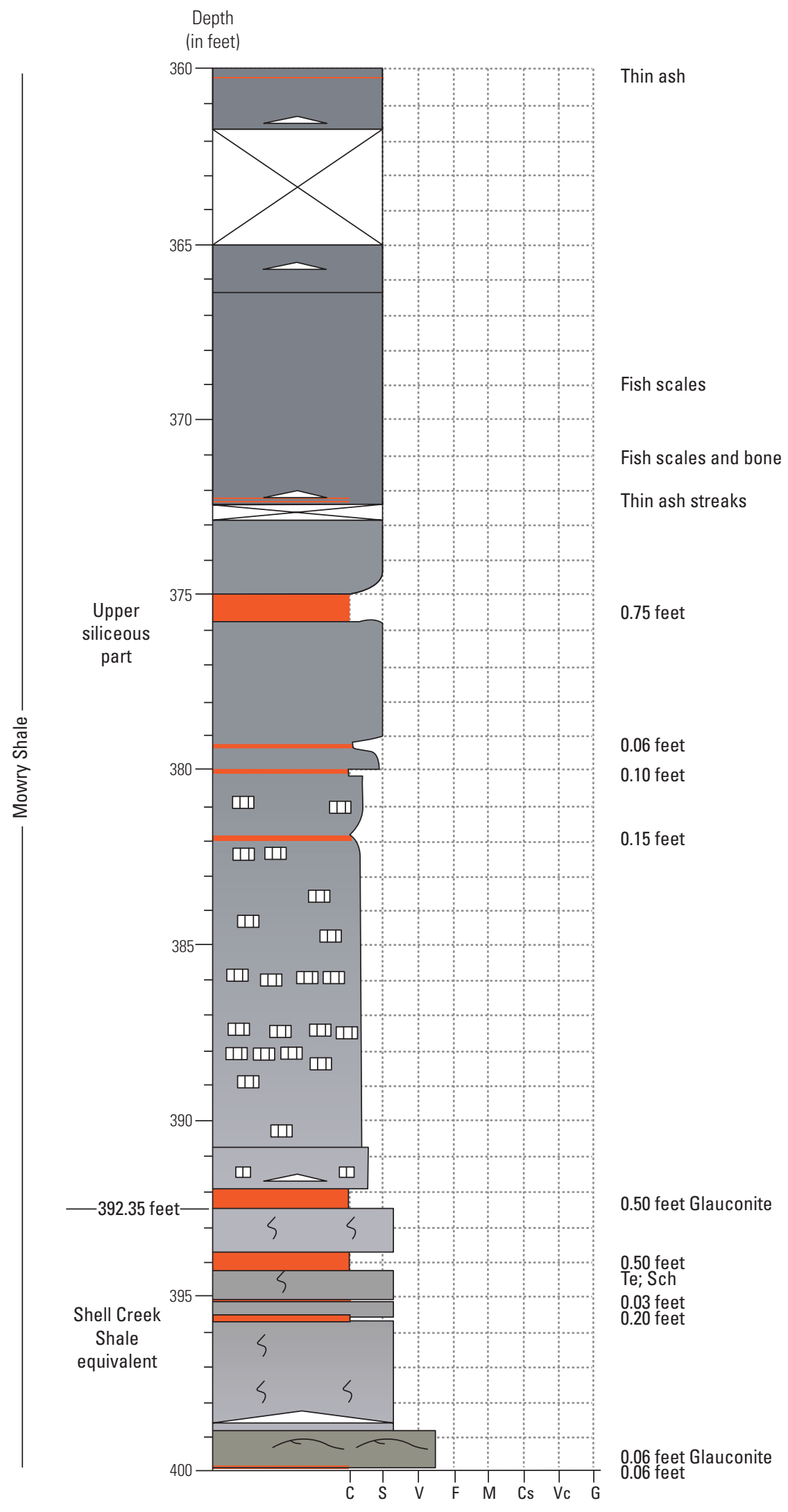




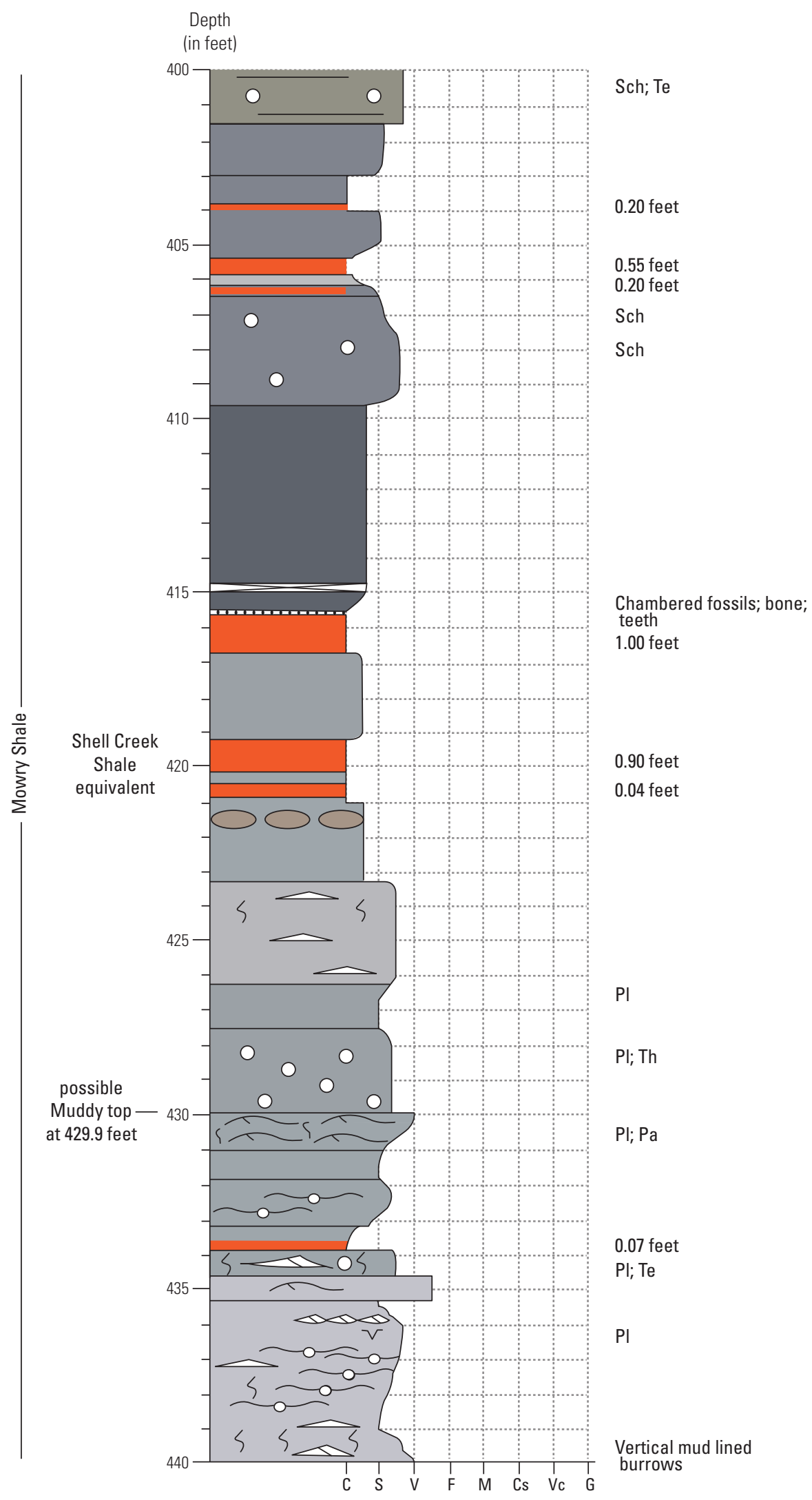




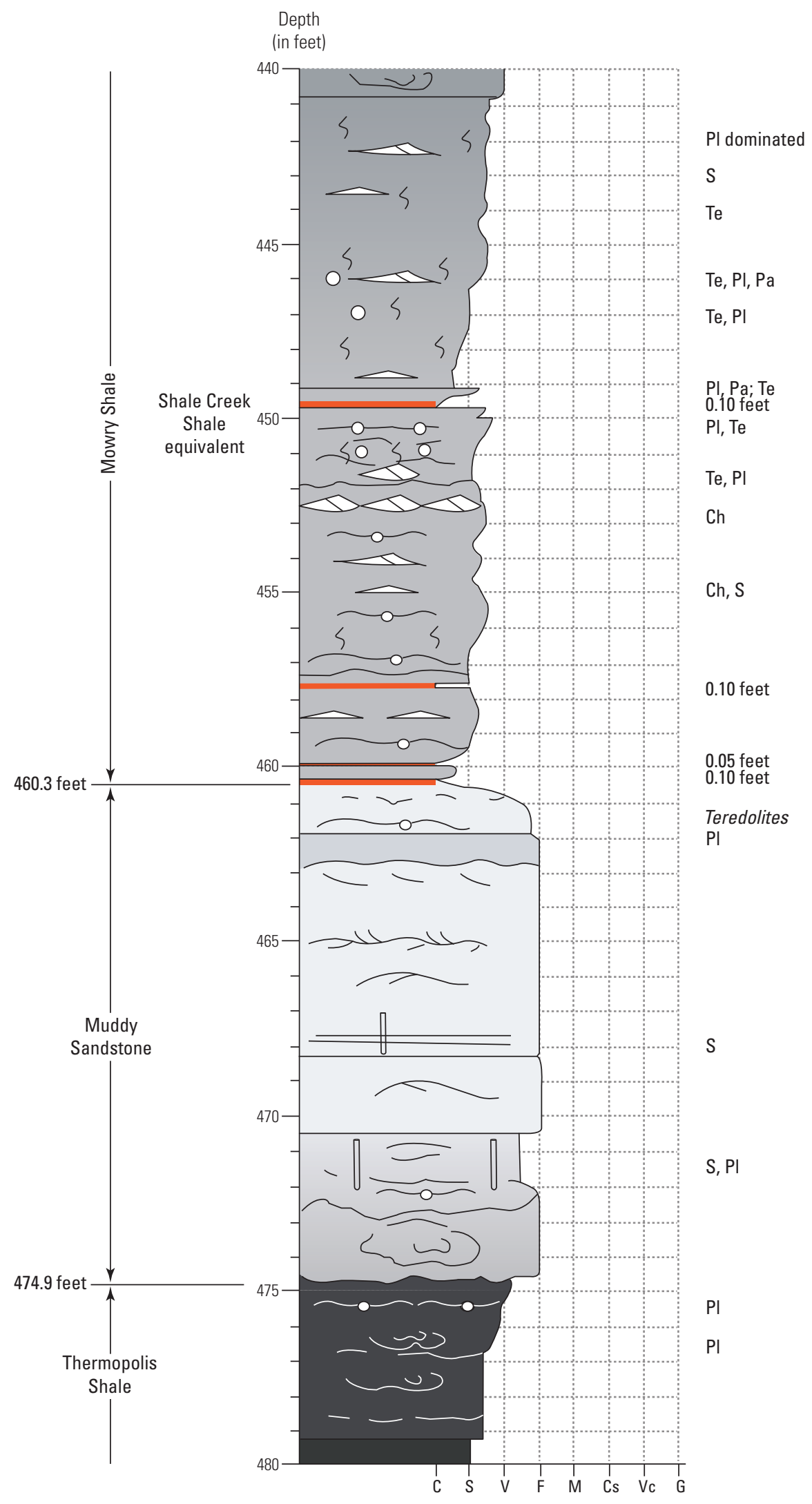




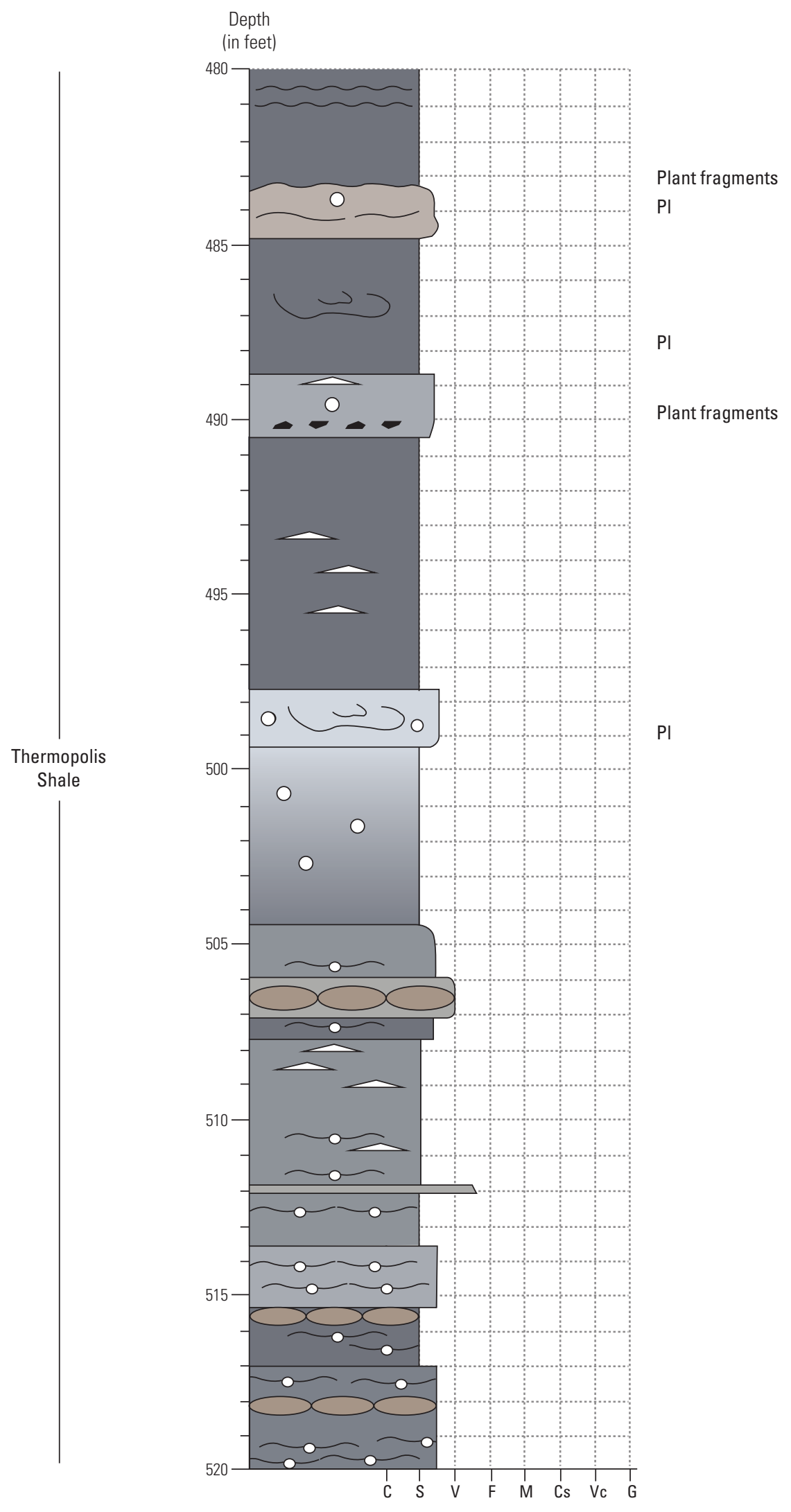




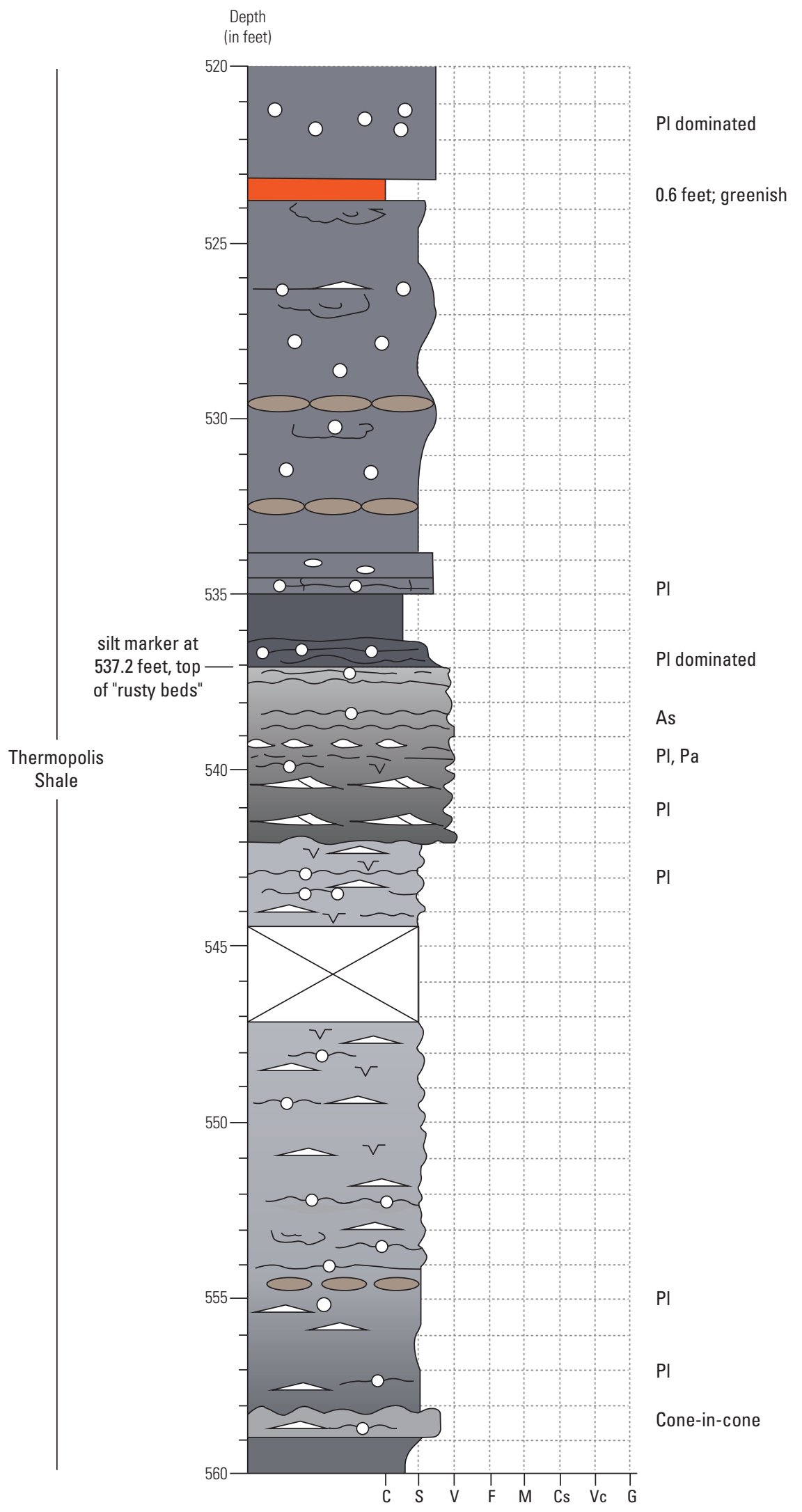




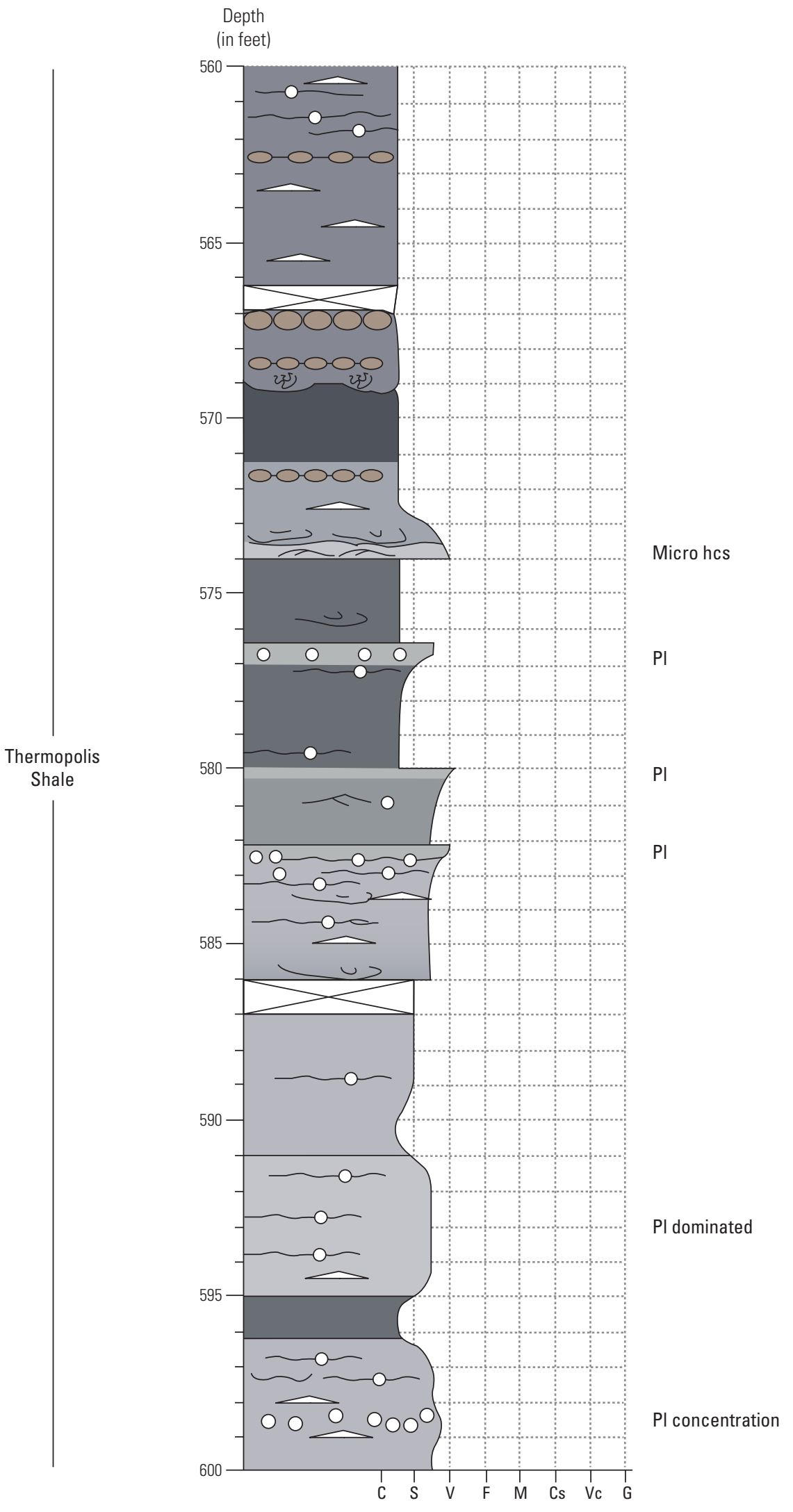




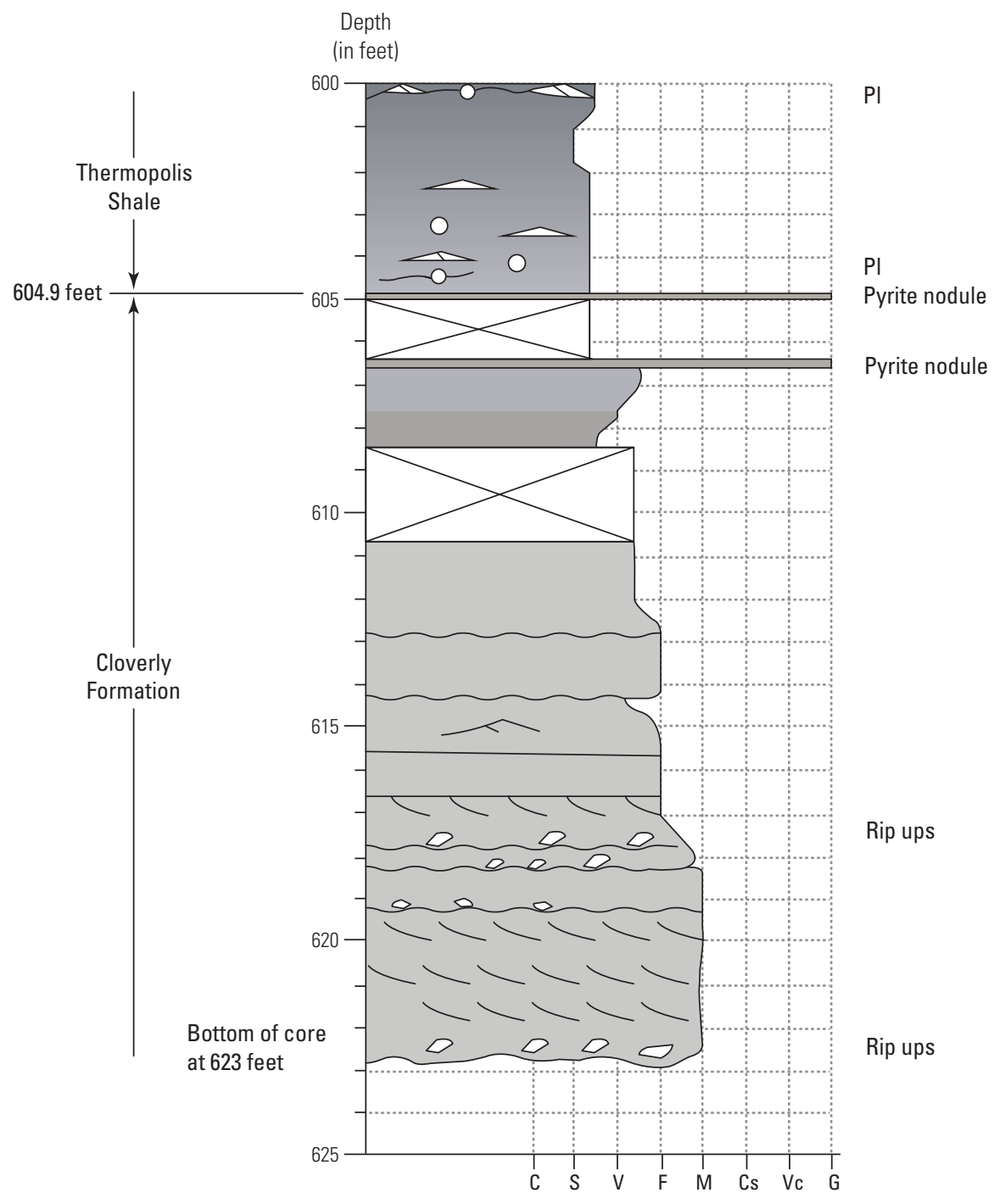

\section{EXPLANATION}

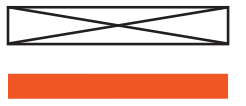

No recovery

Ash bed

Disbursed ash

Colors approximate the actual core color,

except ash beds which are shown in orange

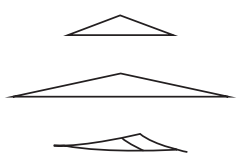

Isolated sand streak

Continuous sand streak or graded bed

Lenticular bedding

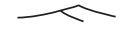

Asymmetrical ripple

$\infty<\infty$

Wavy bedding

Cross stratification

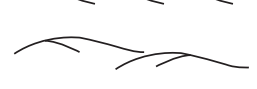

Hummocky cross stratification (hcs)

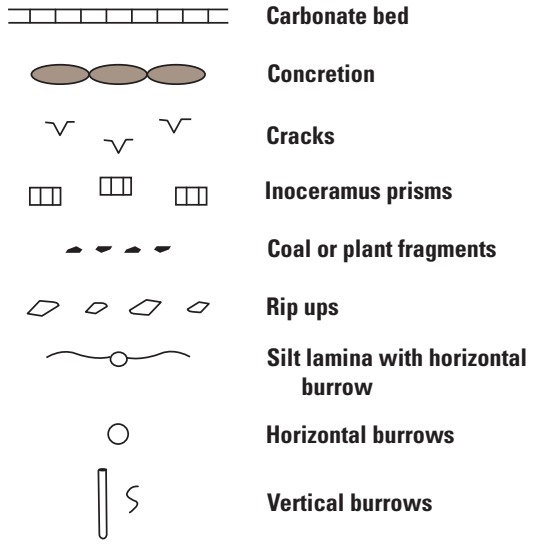

Trace fossils

As Asterosoma

Ch Chondrites

$\mathrm{Pa}$ Palaeophycus

PI Planolites

Sch Schaubcylindrichnus

$S$ Skolithos

Te Teichichnus

Th Thalassinoides

$\widetilde{\sim}$ Silt lamina

W $\rightleftharpoons>$ Convoluted bedding 
Appendix 2. Geophysical Logs of the USGS AR-1-13 Core Hole, Natrona County, Wyoming 

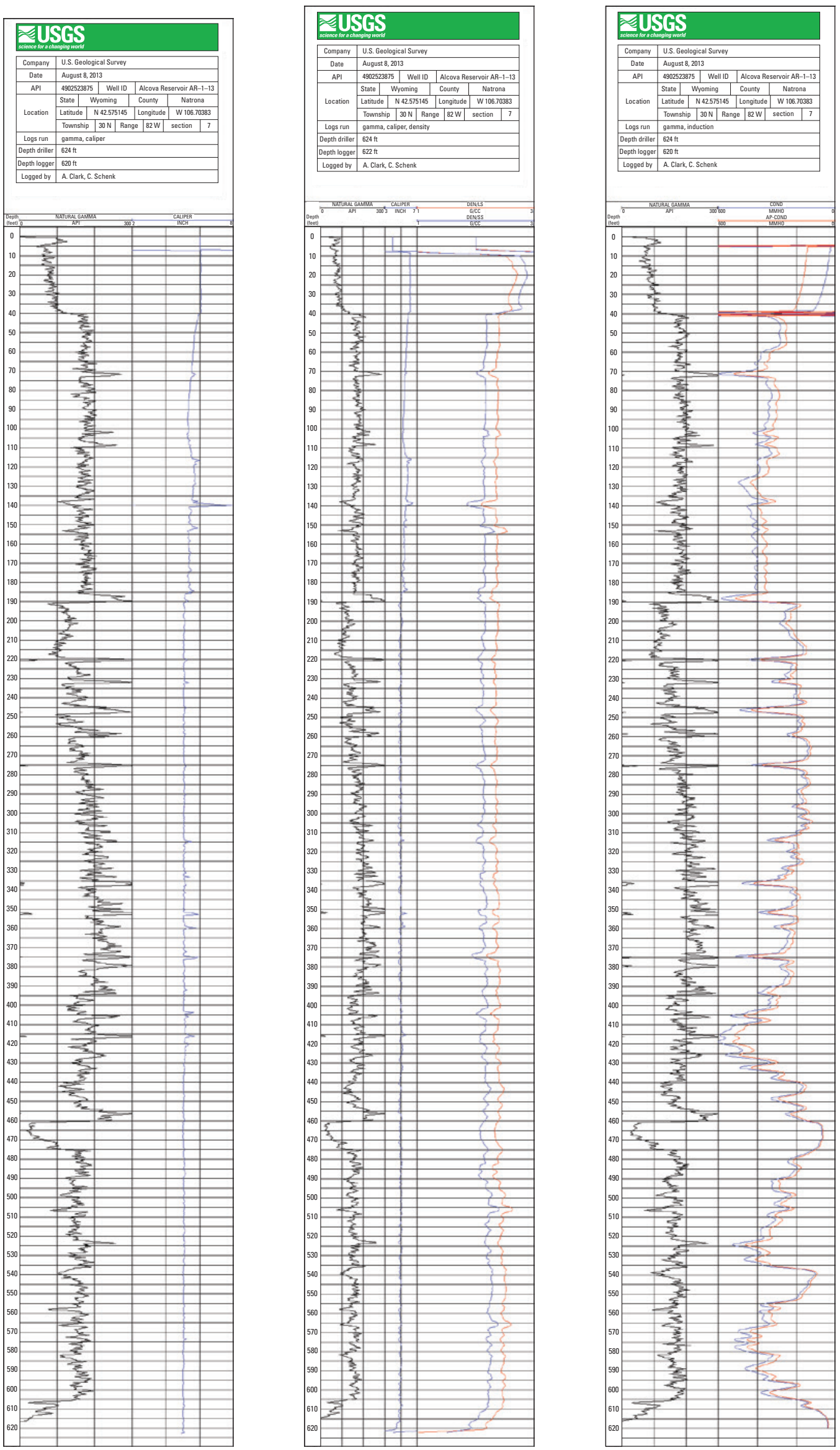

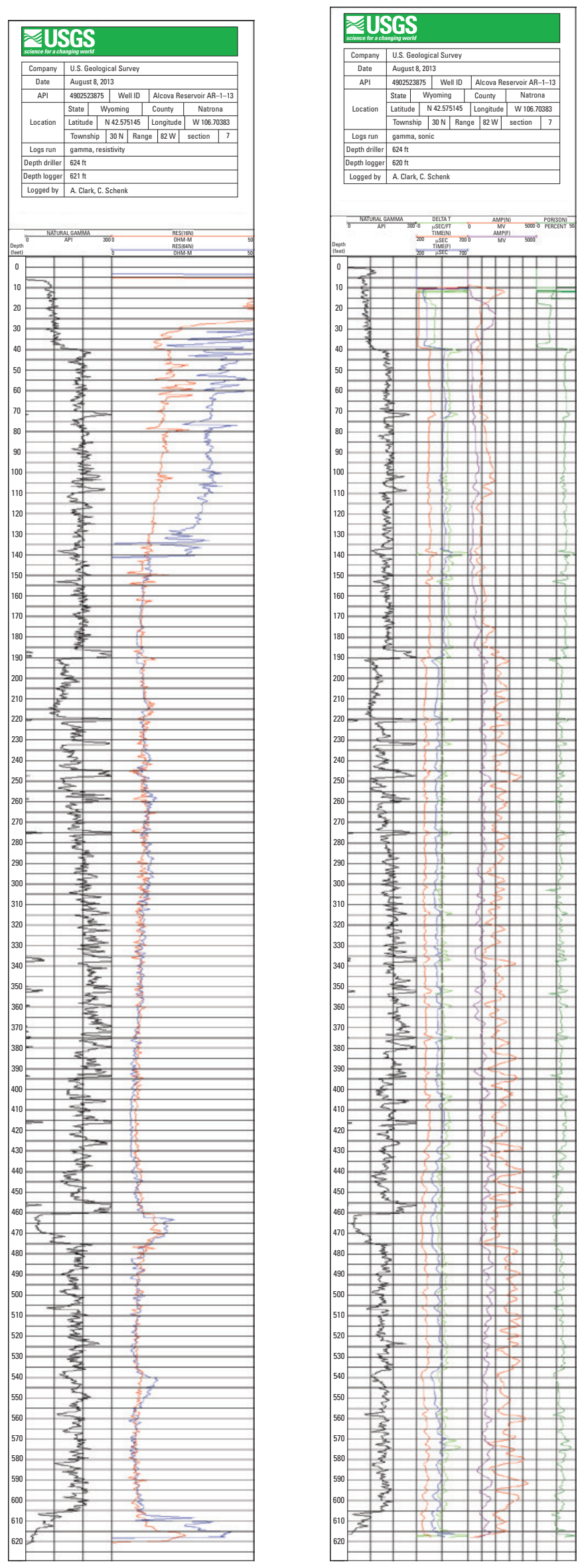
Publishing support provided by the Science Publishing Network, Denver Publishing Service Center

For more information concerning the research in this report, contact the Center Director, USGS Central Energy Resources Science Center Box 25046, Mail Stop 939

Denver, CO 80225

(303) 236-1647

Or visit the Central Energy Resources Science Center website at https://www.usgs.gov/energy-and-minerals/energy-resources-program/ 


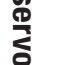

.

$\overbrace{\substack{1 \\ 1}}^{1}$

$\frac{1}{\omega}$

离

증

$\infty$

芯

品

每

$\stackrel{+}{=}$ 